\title{
The Afghanistan-Pakistan Wars, 2008-2009: Micro-geographies, Conflict Diffusion, and Clusters of Violence
}

\author{
John O'Loughlin, Frank D. W. Witmer, and Andrew M. Linke ${ }^{1}$
}

\begin{abstract}
A team of political geographers analyzes over 5,000 violent events collected from media reports for the Afghanistan and Pakistan conflicts during 2008 and 2009. The violent events are geocoded to precise locations and the authors employ an exploratory spatial data analysis approach to examine the recent dynamics of the wars. By mapping the violence and examining its temporal dimensions, the authors explain its diffusion from traditional foci along the border between the two countries. While violence is still overwhelmingly concentrated in the Pashtun regions in both countries, recent policy shifts by the American and Pakistani governments in the conduct of the war are reflected in a sizeable increase in overall violence and its geographic spread to key cities. The authors identify and map the clusters (hotspots) of conflict where the violence is significantly higher than expected and examine their shifts over the two-year period. Special attention is paid to the targeting strategy of drone missile strikes and the increase in their number and geographic extent by the Obama administration. Journal of Economic Literature, Classification Numbers: H560, H770, O180. 15 figures, 1 table, 113 references. Key words: Afghanistan, Pakistan, Taliban, Al-Qaeda, insurgency, Islamic terrorism, U.S. military, International Security Assistance Forces, Durand Line, Tribal Areas, Northwest Frontier Province, ACLED, NATO.
\end{abstract}

\begin{abstract}
A merica's "longest war" is now (August 2010) nearing its ninth anniversary. It was launched in October 2001 as a "war of necessity" (Barack Obama, August 17, 2009) to remove the Taliban from power in Afghanistan, and thus remove the support of this regime for Al-Qaeda, the terrorist organization that carried out the September 2001 attacks in the United States. What appeared to be initial success in removing the Taliban from control in Kabul and the installation of the pro-Western Hamid Karzai government has turned into a protracted guerrilla war with no clear end in sight. In this paper, we provide the local political and geographic context for the ongoing war in Afghanistan and Pakistan and analyze the geographic and temporal distribution of the violence for 2008 and 2009 using media reports. We examine the fighting by the main groups of participants (foreign forces, local police and military, and insurgents) and identify key clusters of violence. As the writing of this article was being finalized, the release of over 76,000 records through WikiLeaks.org that was reported widely in the media offered us the chance to extend the analysis back to 2004 in Afghanistan,

\footnotetext{
${ }^{1}$ Respectively, College Professor of Distinction, Institute of Behavioral Science and Department of Geography, University of Colorado, Campus Box 487, Boulder, Co. 80309 (johno@colorado.edu); Post-Doctoral Research Associate, Institute of Behavioral Science, University of Colorado, Campus Box 487, Boulder, CO 80309 (witmer@colorado.edu), and Graduate Research Assistant, Institute of Behavioral Science, University of Colorado, Campus Box 487, Boulder, CO 80309 (andrew.m.linke@colorado.edu). The authors thank Nancy Thorwardson, Computer and Research Services, Institute of Behavioral Science, University of Colorado for her munificent and cheery demeanor and keen (carto)graphical eye during the preparation of the figures for publication and Clionadh Raleigh, Trinity College, Dublin, Ireland for allowing them access to the unreleased ACLED data for Afghanistan and Pakistan.
} 
to check the validity and completeness of our data against the raw U.S. forces daily logs on the war, and to re-consider our conclusions in light of this newly-released information. The extended report follows in this issue (O'Loughlin et al., 2010b). ${ }^{2}$

When confined to Afghanistan, fighting was concentrated in the eastern and southeastern mountainous terrain of the country where the Pashtun communities provided succor to Osama bin Laden (Al-Qaeda leader) and Mullah Mohammed Omar (Taliban leader) and their allies. These mountains (Hindu Kush) range up to 7,000 meters (25,000 feet) in elevation and have traditionally been the territory from which Afghan groups have launched counterattacks against foreign invaders, including the Soviet Union in the 1980s (Roy, 1990; Rubin, 1995; Rashid, 2010). The Durand Line (1893) marking the boundary between Afghanistan and Pakistan was drawn in a British-Afghan agreement that resulted from the inability of the British to extend their empire into central Asia (Afghanistan) from south Asia (contemporary India, Pakistan and Bangladesh) in the face of indigenous and Russian imperial opposition (Rubin and Rashid, 2008). The Durand Line does not follow any natural feature, and bisects the Pashtun ethnic territory, leaving approximately half of this group in both Afghanistan and Pakistan. Only the Khyber Pass (altitude 1,070 meters/3,510 feet) allows relatively easy access across the northern section of the mountains and as a result, this road through the pass has been the scene of dozens of attacks on convoys linking the two capitals, Kabul and Islamabad, via the important Pakistani city of Peshawar (for all locations mentioned in the text, see Fig. 1).

Using the Pakistani tribal areas across the Durand Line as a safe haven from which to launch attacks on the U.S. and allied forces, the Taliban have managed to stage a revival in Afghanistan, especially over the last three years. Until a change to the Asif Ali Zadari government in Pakistan in 2007 and a declared determination to pressure the Pakistani Taliban (formed in 2002 and known as Tehrik-i-Taliban) by the government, the Afghan war effort by the U.S. and its allies was undermined in the face of this Taliban ability to escape across the Durand Line and to maintain safe havens in its vicinity. Since the beginning of the use of drones (unmanned aircraft that can fire missiles on targets and operated by the Central Intelligence Agency) and the stepped-up Pakistani government effort to eliminate the Taliban strongholds over the past two years, the conflict has seen a sharp rise in violence on both sides of the border. To use the parlance now in vogue in Washington, DC, it is accurate to speak of an "Af-Pak" conflict that has evolved from the Afghanistan front of the Bush "war on terror" of late 2001.

\section{THE CONTEMPORARY CONFLICT IN AFGHANISTAN AND PAKISTAN}

Estimates of the number of civilian casualties in Afghanistan vary, and making such measurements is notoriously difficult in a conflict zone (Benini and Moulton, 2004, p. 420; Lacina and Gleditsch, 2005). However, the UN (UNAMA, 2010) documented over 2,000 combat-related civilian deaths during 2009 alone, and according to the Afghanistan Conflict Monitor at Simon Fraser University (Civilian, 2010), the number of civilian casualties in the conflict has increased every single year since 2006 (from 929 to 1,633 in 2007 to 2,118 in 2008 and 2,412 in 2009) (see also CIVIC, n.d.). Military forces (international and local) and militants are both responsible for this significant rise, and it resulted in a policy shift in June 2009 by the U.S. military under General Stanley McChrystal to try to reduce civilian

\footnotetext{
${ }^{2}$ All of the data, R code, shape files, and other materials that we collected and used in these two papers can be downloaded from the following website for replication purposes: www.colorado.edu/ibs/johno/afpak
} 


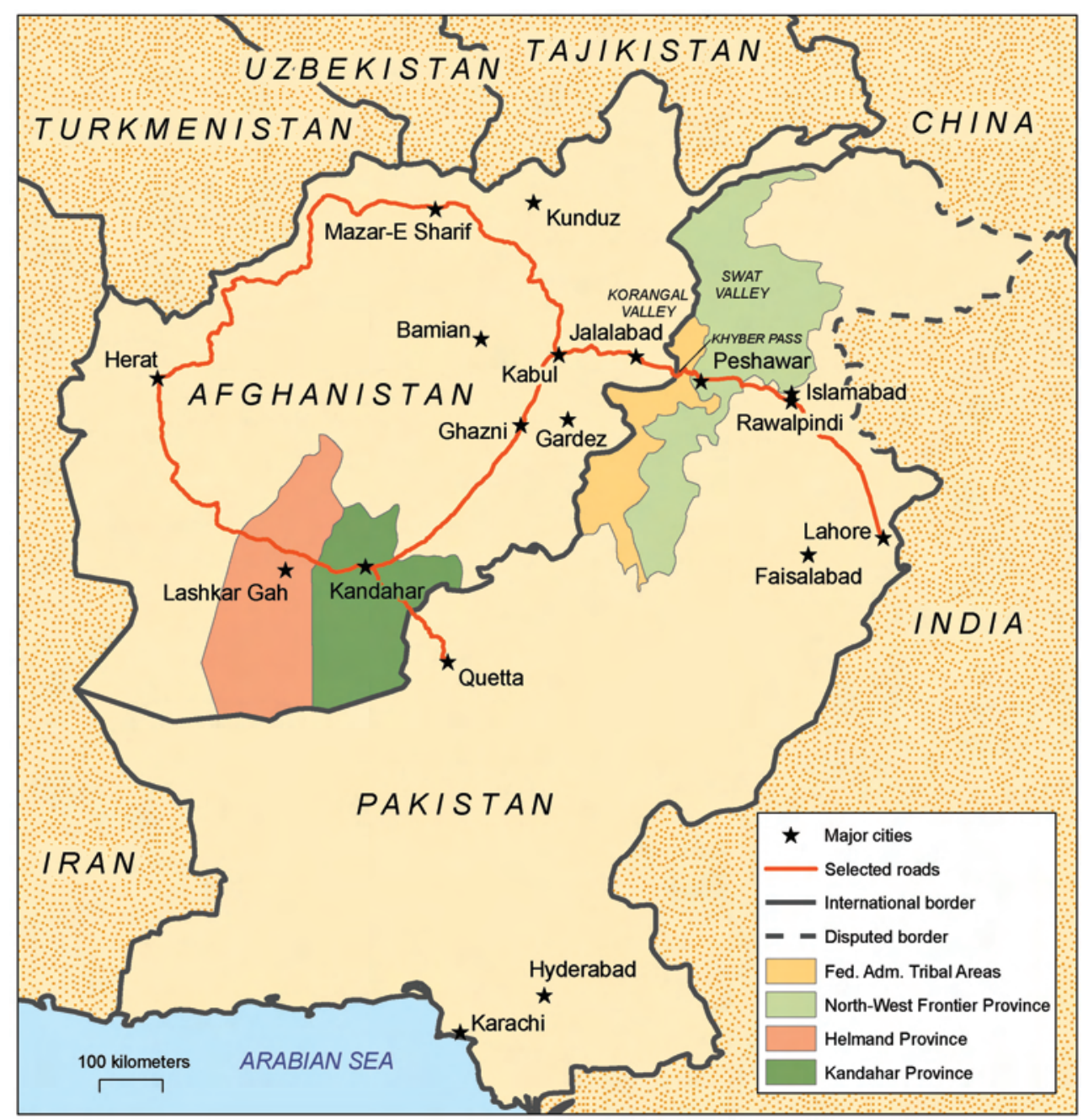

Fig. 1. Key locations in Afghanistan and Pakistan mentioned in the text.

casualities (Filkins, 2009). In Afghanistan, Bird and Fairweather (2009, p. 32) show that suicide bombings rarely hit their military targets, and often kill civilians instead. As Pakistan has now been drawn inexorably into the Taliban conflict, Shah (2010) stresses that an increased reliance on unmanned drone strikes has raised the risk of civilian deaths. In mid-July 2010, nearly a decade after Operation Enduring Freedom (OEF) and after a lull in the early-2000s level of violence, the conflict escalated after 2005 and by mid-July 2010, 1,114 U.S. military and 834 allied foreign forces had been killed and 6,773 Americans wounded (OEF, n.d.; cf. Gritzner, 2010, p. 428).

Afghanistan and bordering regions of Pakistan have now been declared "ground zero of global terrorism" (Acharya et al., 2009). The original NATO-led International Security Assistance Forces (ISAF) mandate had a six-month time frame (United Nations, 2001), and in May 2003 U.S. Secretary of Defense Donald Rumsfield claimed that "the bulk of the country 
today is permissive, it is secure" (quoted in Roi and Smolynec, 2008, p. 297). President Barack Obama has held to his campaign promises of directing the focus of the global "war on terror" away from Iraq and back toward Afghanistan. In December 2009, he ordered a surge of some 30,000 troops to Afghanistan to counter the emboldened insurgency. Therefore, he has adhered to general Bush administration policies, symbolized by maintaining Robert Gates as Secretary of Defense and increasing the Defense Department budget to $\$ 663.7$ billion in 2010. The obstacles to U.S. and ISAF success in Afghanistan are many (Suhrke, 2008). "Powerful warlords; traditions of local, rather than central, governance; the dominance of tribal and ethnic identities over a national one; difficult terrain; a long history of internal conflict and violence" are notable barriers according to Berman (2010, p. 3). Because of these conditions, the complexity and intractable character of violence in the region has encouraged some commentators to label it the "graveyard" of U.S. empire (Jones, 2009). Considering these tangible costs of the U.S. campaign in Afghanistan, it was not surprising that holding dialogue with some elements of the Taliban was proposed as an option for improving Afghanistan security conditions at April 2010 meetings in Washington, DC between US and Afghan leaders (Cooper, 2010).

Our purpose in this paper is to examine the changing dynamics of the war in AfghanistanPakistan over the past two years, from January 1, 2008 to the end of 2009. This two-year period spans the last year of the presidency of George W. Bush and the first year of the Barack Obama presidency. This delineation thus allows us to see if a new war strategy was apparent on the ground and if the loci of violence shifted as a result of the change of administration. It also provides us the opportunity to examine the early results on the ground of the Obama new war strategy that was promised in his campaign for the presidency and implemented in the last three quarters of 2009.

A helpful lens for interpreting the area's conflict is Gregory's (2010a, 2010b) account of two typologies of "new war." The first type, known as the "Revolution in Military Affairs" (RMA), is characterized by advanced technology, precision weaponry, and the efficient management of specialized combat operations with the entire globe as the theater of operations (Shaw, 2002; O'Loughlin, 2005a; Dalby, 2009). The other form of new war is characterized by localized combat dynamics, small and flexible militant units, improvised weapons techniques, and a pre-modern (almost atavistic) character. Conflicts falling within this category are most evident in the intra-state civil wars of the Global South. The contemporary Afghanistan campaign illustrates an encounter between paradigmatic examples of each type of new war. Insurgents in the region represent the latter, planting roadside bombs under cover of darkness and placing civilians on rooftop sniper positions to prevent retaliation from the most powerful and advanced military in the world, representing the former RMA approach. Our study uses a spatial lens and a disaggregated approach to investigate the patterns of conflict that characterize the meeting of these two "new wars." Unlike Beck (2003) and Shroeder (2005) in their accounts of their research on the "war on terror" front in Afghanistan, we provide full disclosure of our data (geolocated violent events) and methods (GIS, remote sensing, and geostatistical) in line with O'Loughlin's (2005b) call for transparency and disclosure in academic work.

\section{THE HISTORICAL CONTEXT OF CONFLICT IN THE AFGHANISTAN-PAKISTAN REGION}

In what is commonly referred to as the "Great Game," British and Russian territorial ambitions collided in Afghanistan during the 1800s (see also Gritzner, 2010, p. 421). Viewing 
Russian expansion into Central Asia as a potential threat to colonial India, Britain saw the control of Afghanistan as a geopolitical necessity, a buffer against the Russian-controlled territory. Local resistance to outside intervention became evident during the first Anglo-Afghan war in the 1830s. Infractions along the Durand Line as the border of colonial India led yet again to open combat between the Afghans and the British in the years following World War I. Following an armistice, Afghanistan gained full independence, and the Durand Line was reaffirmed.

The Pashtun-dominated areas of Western Pakistan (see Fig. 1 in Mustafa and Brown, 2010, this issue) have become, in effect, an extension of Afghan territory because the population of the Tribal Areas pays little attention to the boundary and Afghanistan refuses to accept the border's legitimacy (Jones, 2002, p. 144). In areas of conflict, "multiple zones of military and political control emerge, giving rise to partially overlapping loyalties and identities" (Chojnacki, 2006, p. 40). Individuals often show attachments to communities at different scales, a pattern called "nested identities" (Herb and Kaplan, 1999). These identities are characterized by broad (e.g., country) categories, but also by very specific classifications (e.g., tribe) under different circumstances. This concept helps explain how Pashtun identity can be a cohesive factor at the regional scale, and how local-level diversity is also important for understanding the region. Johnson and Mason (2008, p. 52), for instance, emphasize that "national feelings and loyalties are filtered through successive layers." Pashtuns can also be accurately described as consisting of five major groups (Durrani, Ghilzai, Sarbani, Ghurghusht, and Karlanri) and several hundred tribes within each subset. The salience of relational ties within local groups emerges as an impediment to establishing sound governance with wide support (Angstrom, 2008).

In 1953, General Mohammed Daud became Prime Minister of Afghanistan and turned toward the Soviet Union for development assistance and military aid. Pressing for progressive social reforms, and under pressure for supporting the creation of "Pashtunistan" that would include Pakistani territory, Daud was forced to resign in 1963, later returning as President following a 1993 coup. Conflict erupted in Kabul in 1978 between pro-Soviet and pro-American/ Pakistan advocates, and after 25 years of unstable governments, a new regime was installed in Kabul in 1980 by the Soviet invasion. As part of a revived Cold War geopolitical maneuvering, the U.S. began funding the opposition (mostly conservative Mujahideen) through Pakistan's Inter-Services Intelligence (ISI) agency and supplying both weapons and training. With Afghanistan devastated by five years of intense conflict, Mikhail Gorbachev declared in 1985 that the Soviet Union would withdraw its forces, though they remained until 1988. In the aftermath of the Soviet involvement, Afghanistan's pro-Soviet leader, Najibullah, was overthrown and the Taliban, emerging from the Kandahar region, took power in Kabul in 1996. Although they never controlled all parts of the country nor stopped the fighting between factions vying for regional control, the social atmosphere in the Taliban-controlled regions was marked by adherence to conservative Islamic codes, and strict enforcement of sharia law.

"Operation Enduring Freedom" (OEF) began with the deployment of U.S. Special Forces in October 2001 to topple the Taliban. At that point, Afghanistan had experienced highintensity civil internal conflict for 22 years, with an estimated 2 million casualties (Benini and Moulton, 2004, p. 419). U.S. forces, working with the anti-Taliban Northern Alliance (supported by Russia since the Soviet pullout), quickly secured control of Kabul, Mazare-sharif, Herat, Jalalabad, and other key cities (see Fig. 1 for locations). A December 2001 UN meeting in Bonn set up the Afghan Interim Authority with Hamid Karzai at its head and UN Security Council resolution 1386 (20 December) established the NATO-led ISAF with a mandate to provide security for the interim government. Deployed only in Kabul initially 
and consisting of 4,500 troops, as of the end of June 2010, ISAF commands 119,500 troops throughout Afghanistan, of whom 78,430 are American. According to official figures, 2009 was the most deadly year to date for ISAF forces, with 520 soldiers killed, nearly double the number of fatalities the year before.

Nearly half of all Afghan citizens are pessimistic about the future because of rising insecurity (Mullen 2010, p. 129). For almost a decade, Afghans have seen heavy fighting between Taliban insurgents and ISAF forces. While insurgent groups in the region may have different goals, they are unified in their desire to expel foreign forces. Hezb-e-Islami, for instance, has fought Taliban leadership in the past, although more recently the two groups have combined their efforts. Pakistan, strategically, has supported various Afghan groups in the past including the Mujahideen during the Cold War. In 1996, Pakistan was one of only three states to recognize the Taliban as leaders of Afghanistan (others were Saudi Arabia and United Arab Emirates). Because of these past relationships, the Pakistani commitment to defeating Pashtun insurgents has been called into question and even now, Pakistan stands accused of continuing this support through its ISI agency, as evidenced in the Wikileaks.org files (Mazzetti et al., 2010; see also Fair and Jones, 2009 and Shah, 2010). Claims of Pakistan's complicity have strained the relationship between the U.S. and Pakistan and President Musharraf had to deny publicly that the ISI had turned a blind eye to militant activity (Human Rights Watch, 2007, p. 22).

A consultant to U.S. State Department and Pentagon officials, David Kilcullen (2009, p. 47), for example, notes that, "as of mid-2008, the insurgency was increasing its geographic spread and level of violence ... According to UN assessments, the insurgency also spread into much of western Afghanistan, particularly Baghdis Province, and into interior provinces like Lowghar, Kapisa, and Wardak that used to see very little insurgent activity.” Johnson and Mason (2008, p. 60), claim that "insurgency in Afghanistan has always sprung from the hills ... and the Taliban is no exception." Of fluctuations in violence between 2008 and 2009, Mullen (2010, p. 128) writes that, "insecurity spread geographically from the formerly insecure areas in the southeast to the west and north, including the capital Kabul.” Indeed, the Pentagon recently accepted that the government and Allied forces only control 29 of 121 districts in Afghanistan (Dalrymble, 2010).

Conflict in one country is inexorably tied to insecurity in neighbors, but we need also to consider broader geopolitical relationships. Beyond the co-ethnic bond linking Pashtun populations across the Afghanistan/Pakistan border, several additional factors influence the relationship between the two countries. A history of antagonism, including the disputed territory in Kashmir, has caused Pakistan to be wary of India's role in Afghanistan's reconstruction, including construction of the new Parliament building in Kabul, road networks in Nimruz Province of Afghanistan's southwest, and a hydro-electric dam project in northern Herat Province. According to the Council on Foreign Relations, from 2001 to 2009, India has donated $\$ 1.2$ billion to fund infrastructure and institutional development in postTaliban Afghanistan (Bajoria, 2009). The tit-for-tat logic of Pakistani and Indian activity in Afghanistan is clearly strategic (Rubin, 2007; Fair and Jones 2009, p. 162;) and was the driving force behind Indian support for the Tajik, Uzbek and Hazara-dominated Northern Alliance during Taliban rule.

\section{THE DIFFUSION OF CONFLICT IN PAKISTAN}

Previous research in the field of conflict studies has shown that violence knows no borders. Rather, conflict is typically characterized by space-time diffusion processes across 
administrative boundaries (O'Loughlin and Anselin, 1991; Buhaug and Gleditsch, 2008). These contagion processes have also been identified using sub-national, disaggregated conflict event data (see the review in Raleigh et al., 2010a). The forces that underlie space-time conflict diffusion can be numerous, but for the Afghanistan-Pakistan case, the most relevant is the strong trans-boundary ethnic ties among Pashtuns (e.g., Braithwaite, 2010, p. 313). Maintaining and policing border areas is easier said than done along the rugged AfghanistanPakistan border. Approximately 2,500 km long, there are only two official border crossings: Torkham at the Kyber Pass, and Chaman between Kandahar and Baluchistan provinces in Afghanistan and Pakistan, respectively (see the roads in Fig. 1). Expecting the local populations to rely on only these two crossings is unrealistic and, therefore, it is estimated that there are 111 illegal and unregulated crossings along the northern portion of the border and at least 229 in the south (Johnson and Mason, 2008, p. 44).

Because of cross-border insurgent activity, Pakistan has been inexorably drawn into discussions of Afghanistan's fate. Recognizing that conflict can diffuse across poorly regulated borders is a key component of geographic approaches in the academic study of conflict and this phenomenon is also a well-known reality for those with experience in the region. For example, U.S. Army General and NATO commander David McKiernan (2009) stated that defeating insurgents represents a "regional problem set" requiring an "Afghanistan-Pakistan approach." This is especially true because the conflict is sometimes viewed as a Pashtun-led insurgency (e.g., Johnson and Mason 2008, p. 73). A senior policy analyst, Bruce Riedel, has similarly suggested that "we cannot de-link Afghanistan and Pakistan" (quoted in Riedel et al. 2010, p. 4). The former US ambassador to India and later security advisor in the Bush administration, Robert Blackwill, has advocated a "de facto" partition of Afghanistan between Pashtun and non-Pashtun regions because he believes that the insurgency is a Pashtun nationalist movement and will not be defeated by the current Kabul regime supported by the West (Blackwill, 2010).

While many Afghan Taliban escaped across the border with Pakistan during the beginning of OEF, they are not only using the territory as a safe haven to launch attacks inside Afghanistan. Rather, it is now clear that many costs associated with the conflict in Afghanistan are being felt within Pakistan. Due to skirmishes that have stemmed from the influx of Afghan Taliban, as many as one million residents of the Federally Administered Tribal Areas (FATA, hereafter Tribal Areas; Fig. 1) have fled into other parts of Pakistan (ICG, 2009). Evidence of these effects appear also in official discourses, including President Pervez Musharraf's order in 2007 that members of the Pakistani armed forces not wear their uniforms in public, as doing so puts them at risk of attack by a revitalized Pakistani Taliban (Fair and Jones, 2009, p. 177).

Further complicating the situation, Pakistan's Tribal Areas were already governed under very limited federal management. Pakistan's president has executive authority over the region but beyond this role, normal functions of governance are carried out by Political Agents through the Bureaus of seven agencies (Bajaur, Mohmand, Khyber, Orakzai, Kurram, North Waziristan, and South Waziristan). Agents are under the authority of the Governor (appointed) of the Northwest Frontier Province (NWFP) in Peshawar. Each agency has representation in Pakistan's National Assembly. In the Tribal Areas, there is little oversight of public service provision, patronage ties regulate loyalty, and corruption is rife (Jones, 2002). Locally, the Taliban in Pakistan pose a threat to traditional elders' rule. Conflict is spreading in Pakistan. "Terrorist violence that had been restricted to the tribal areas of the NWFP spread beyond this region to the heart of Pakistan in 2007" (Khan, 2007, p. 146). In June 2010, The Economist reported that extremists (Taliban and their allies) had grown significantly stronger outside the 
tribal areas in the border with Afghanistan and had developed the capability to wage major attacks in the Punjabi heartland of central and eastern Pakistan (The Punjabi, 2010).

In the face of U.S. pressure to bring order to the region, a stand-off between Pakistan's armed forces and pro-Taliban leaders in North and South Waziristan agencies in 2006 illustrates the ambiguous federal-local relationship. In this case tensions ended with Pakistan withdrawing its troops on the condition that Tribal Areas leaders not support armed raids into Afghanistan. Nevertheless, the months following the agreement were the most deadly that ISAF forces had yet seen in Eastern Afghanistan (Human Rights Watch, 2007, p. 24). Before a full year had passed, in summer 2007 Waziristan leaders openly turned their backs on the agreement. A newer 2009 agreement with the leaders of the Northwest Frontier Provinces (also called Khyber Pakhtunkhwa), endorsed explicitly by President Zardari, allowed for the institution of sharia courts, a clear abrogation of juridical authority by the Pakistani government.

U.S. drone strikes now characterize the expansion of fighting outside of Afghanistan's territorial borders. Though U.S. troops are not allowed to operate on the ground in Pakistan, the U.S. is active nevertheless, with at least 89 drone strikes in 2008 and 2009. The CIA was authorized by the Obama administration in late 2009 to expand the scope and intensity of drone attacks on Pakistan's territory (Shane, 2009). Debates surrounding the new reliance upon drone strikes have raised a complex array of sovereignty and accountability issues, legally within the U.S. and politically in Pakistan.

There are two ways that insecurity has spread across the Afghanistan-Pakistan border. The first is direct, based on an understanding of the tangible and immediate-term impact of militant and counter-insurgent activity on local border communities and is investigated in our study of the temporal-spatial occurrence of violent events. The less tangible manner in which Afghanistan's violence affects Pakistan is by increasing the likelihood of long-term, structural, domestic strife. Grare (2007, p. 143) suggests that American pressure on the Pakistani government to deal with militants in the north and west regions may "gradually alter the balance of power within Pakistan itself." What began as an inter-state war in a neighboring country is now fostering the conditions for higher rates of intra-state conflict within a state (Pakistan) that was not party to the initial conflict.

Supporting this view, the Pakistan Institute for Peace Studies data reveal that 2009 was the deadliest year for suicide attacks in Pakistan's history, with the majority of deaths occurring in the provinces bordering Afghanistan (Tribal Areas, NWFP, Baluchistan) (PIPS, 2010; see also Mustafa and Brown, 2010). While sectarian conflict has plagued Pakistan for decades, Grare (2007, p. 127) emphasizes that this violence has always had broader "geopolitical roots." The dynamics of violent events in neighboring Afghanistan contributes to these roots of conflict. In terms of stability, Pakistan performs quite poorly due to a number of internal factors such as highly uneven standards of living among its provinces, ethnic tensions, and the fact that a large number of citizens support conservative religious platforms. In 2010, Pakistan ranks tenth on Foreign Policy magazine's Failed States Index (FP and TFFP, 2010), and its score is far worse than any of the previous three years (Afghanistan ranks sixth). The presence of sectarian and anti-Indian groups, in addition to organizations that are associated with the Taliban or Al-Qaeda, is making a serious problem even worse (Tellis, 2008) — pushing the country to the brink of state collapse.

Though security in the tribal areas of Pakistan is not likely to improve without better political, social, and economic management from Islamabad (Markey, 2008), efforts to deal with militants in the Tribal Areas and NWFP are heavy handed, a criticism that can also be applied to the treatment of the Baluch nationalist movement (southwestern Pakistan) over the 
past 50 years. Locals feel that collective punishment is imposed for militant infractions (Fair and Jones, 2009, p. 177). A 2008 poll showed that close to half (46 percent) of residents in the border region support working with the Taliban to develop a solution (Fair et al., 2008), while another national poll showed that the majority of Pakistan's citizens view the Pakistani Taliban as a critical threat to the country (Ramsey et al., 2009).

\section{THE CONFLICT STUDIES LITERATURE AND THE WARS IN AFGHANISTAN AND PAKISTAN}

Within the conflict studies literature, violence in Afghanistan has received attention from several broadly defined subfields. First, the strategic studies community has used the Afghanistan case for investigating how tactical decisions are made (e.g., King, 2010) and whether the tactic of placing Forward Operating Bases (FOBs) in Helmand Province has been effective. Wilner (2010) has studied violence in the country to investigate the effectiveness of targeted killings of insurgent leaders, claiming that incidents of suicide attacks fall after such operations. Using a comparative approach that includes the example of Chechnya (Russia), following violence in the republic during the 1990s, Fayutkin $(2009$, p. 369) finds that a "stabilization phase" directed by assertive leaders is critical for a government to maintain a firm monopoly on violence.

The second area of research examines violence itself (especially civilian casualties), and the effect of conflict on the lives of everyday citizens. Fluri (2009), for instance, investigates how victimhood is translated into a global discussion of warfare's collateral damage in Afghanistan. Using data from May 2006 to October 2009, Bird and Fairweather (2009) compare varying types of militant attacks in Afghanistan and Iraq, finding that in Afghanistan, insurgents have relied increasingly on indirect methods of attack, such as indiscriminate roadside bombs. Benini and Moulton (2004) model the factors that contributed to high rates of civilian death during OEF using data gathered from 600 communities throughout the country. In contrast to the "precision" narrative of RMA war, their results suggest that civilians suffered greatly during the battles between ISAF and the Taliban.

The third general focus of research on conflict in Afghanistan is an institutional approach to post-conflict reconstruction and state-building. Comparisons with previous U.S. experiences of promoting democracy are common. Berman (2010) goes so far as to suggest that the international community look toward tumultuous 17th century France for solutions to the crisis in Afghanistan. For her, "warlords" and "tribal chiefs" in contemporary Afghanistan equal the "nobility" and "clergy" of Europe's past. Other studies (e.g., Geller and Alam, 2010) have shown that co-ethnic relations among Pashtuns are a key factor that drives the decision of some Afghan community leaders to side with the Taliban, rather than with NATO-led ISAF troops and the Afghan national administration. Also within the context of developing governance institutions, Angstrom (2008) argues that choosing sides in this fashion can be very difficult when the identity of the long-term victor remains uncertain. As such, fence-sitting is a deliberate strategic choice. Furthermore, amid a flurry of corruption accusations against Afghan officials, Their (2010, p. 133) points out that many civilians see little reason to "risk their necks" in support of a deeply flawed national administration. Civic-action and reconstruction campaigns are thus often seen as tools of "co-optation" in the eyes of community leaders (Polk, 2010). With little payoff for investing in reconstruction, Roi and Smolynec (2008) believe that ISAF has abandoned the relatively limited aims of OEF, and taken on the costs of spreading itself too thinly across the territory. 


\section{DATA, METHODS, AND RESULTS}

The data and methods of this paper are similar to those that have been used for analysis of violence in other war theaters, by Hegre et al. (2009) for Liberia, by Raleigh and Hegre (2009) for central Africa, by Siebeneck et al. (2009) for Iraq, and by O'Loughlin and Witmer (2010) for the North Caucasus of Russia. With the end of the Cold War, academic analysis of the most common type of contemporary conflict, civil wars, turned to examination of finely grained data that pinpoint the locations of violent events (Cederman and Gleditsch, 2009). Rather than seeing a civil conflict as encompassing the whole country (few are that expansive), the current emphasis is on the analysis of the local dynamics of violence and has consistently indicated the localized nature of contemporary wars. Advances in spatial statistics have been motivated by the "turn to the local" (Fotheringham, 1997) and the ebb and flow of violence can be correspondingly mapped, investigated, and projected. The parallel development of statistical tools for point data (in our case, georeferenced violent events) and the developments in geographical information science have eased the difficulties of managing and merging large data sets.

New insights into the changing patterns of violence, usually sorted by actor (instigator of a particular violent event), have clarified that civil strife not only has multiple layers of causal factors that are hard to separate but have also made clear that the so-called "geography" of civil war is relatively poorly understood compared to other elements. While sophisticated theories of the motivations of rebels have been debated and replicated in multiple settings, much of the consideration of geographical variables is still rudimentary. Compared to the decade-old debate between adherents of the "greed" (economic motivations) and "creed" (social and cultural factors) hypotheses (see Dixon, 2009 for a review), the limited consideration of the role of geographical factors in war is evident and is often confined to gross measures such as of forested and mountainous areas, of distance to the capital city, or of peripheral location (Buhaug et al., 2009). Despite references to "geography," the current literature is characterized by relatively little attention to spatial-statistical approaches and analysis (Raleigh et al., 2010b; O'Loughlin and Witmer, 2010). We redress that imbalance in this paper by choosing exploratory methods of spatial analysis to document the shifting patterns of violence in the Afghanistan-Pakistan war theater. Emphasizing graphic and cartographic displays of the large number of violent events (5189 in all) over the two-year period, we gauge the effect of the escalation of violence on the various regions of the two countries, estimate the extent of its spread, and identify the hotspots of violence through the use of a spatial scanning method originally developed for detection of disease clusters (Kulldorf et al., 2005). ${ }^{3}$

Violent event data for our analysis are drawn from the Armed Conflict Location and Event Data (ACLED) project (Raleigh et al., 2010a). Information for the time, location, and character of events are recorded from international sources (e.g., BBC Monitoring, LexisNexis, Factiva, and others) and local English-translation sources where available (e.g., militant reports to Pakistan's DAWN media group). Because the goal of the data project is to gather at the finest resolution possible, only one report is required per event. An example will act as a helpful illustration of the collection and coding. On April 5, 2009, according to BBC sources, Afghan authorities claim that 11 Taliban officers were killed by their troops in Baraki Barak, Logar Province. The event, having occurred between two armed groups - insurgents and the Afghan National Army (rather than including unarmed civilians) - is coded as a battle

${ }^{3}$ All analyses conducted in R 2.10.1, ArcGIS 9.3, or SaTScan 9.0.1. Data and script files (for R and Python) are available online at www.colorado.edu/ibs/johno/afpak/ 
event. The exact location of the event is known, and latitude and longitude coordinates are assigned with "geoprecision" level 1. The codebook and other information for ACLED data is available online (ACLED, n.d., at www.acleddata.com).

We analyze the Afghanistan-Pakistan wars as a series of questions that are answered by reference to the distributional patterns (cartographic and graphic) of the violent events. We engage in an exploratory analysis, rather than testing specific hypotheses, and the methods that we select are expressly designed for this initial foray into the changing nature and geography of the related conflicts. We pose three main questions about the character of the war to guide our analysis and discussion.

\section{Question 1: Has the Intensity and the Location of Violence Changed Since President Barack Obama Came to Office?}

In a policy change announced on March 27, 2009, Barack Obama significantly increased the U.S. commitment in troops and financial support to the war in Afghanistan. Later, in early December 2009, he committed a further 30,000 troops to the war effort. Though our data (to the end of 2009) cannot provide a full picture of the changes induced by the late 2009 troop surge, the comparison of 2008 to 2009 allows an early view of the strategic changes on the ground from Presidents Bush to Obama as reflected in the geographic distribution and number of violent events. We show the geographic locations of violence, provide summary spatial statistics of its distribution, and break it down by type of location (urban-rural) and by actor. Furthermore, our data highlight temporal trends by quarterly and monthly periods.

Figure 2 shows all ACLED events in Afghanistan and Pakistan for 2008 and 2009. The events are widely distributed across the two countries, although concentrated along the Afghan/Pakistan border, especially near Kabul and Peshawar. To assess the distribution of events based on which actors are involved, we divided the events into three categories, those involving foreign forces, local forces, and insurgents. The ACLED data are structured such that each event can be coded with two actors and an ally for each of those actors. For many events, it is difficult to determine who is the aggressor, and therefore we denoted foreign forces events as any entry in the database that had an international component as any one of the four possible actors. Even if the primary actors were the Afghanistan military and Taliban, with the International Security Assistance Force as an ally, we coded it as a foreign forces event. Foreign forces events primarily involved troops from member countries of ISAF. ${ }^{4}$

Local force events were selected from the remaining non-foreign events by searching for Afghanistan and Pakistan government forces in any of the four actor fields. Typical actors for these events are police and armed forces from each country. ${ }^{5}$ All remaining events were classified as insurgent events, and primarily consist of violent actions against civilians. By this coding schema, we are undercounting the number of insurgent attacks on coalition and government forces. ${ }^{6}$ Of the 5,189 total events in Afghanistan and Pakistan for 2008 and 2009, 1,529 are classed as "foreign forces," 2,011 are classed as "local forces,” and the remaining

\footnotetext{
${ }^{4}$ The exact search terms used for the foreign forces category are "ISAF|International|United Nations $\mid$ Australia|B elgium|Britain $\mid$ Canada $\mid$ Czechoslovakia|Denmark|Estonia|Finland|France|Germany|Hungary|Italy $\mid$ Latvia|NATO|Neth erlands|Norway|Poland|Romania|Spain|States|Sweden|US Military|US Protection|CIA|Foreign" where “|” signifies "or" in the R search syntax.

${ }^{5}$ The exact search terms used for the local forces category are "Afghanistan Armed Forces|Forces of Afghanistan|Government of Afghanistan|Security of Afghanistan|Forces of Pakistan|Pakistan Armed Forces|Police|ISI Agents|Private Security".

${ }^{6}$ Our companion paper (O’Loughlin et al., 2010b) examines the insurgent activity more closely.
} 


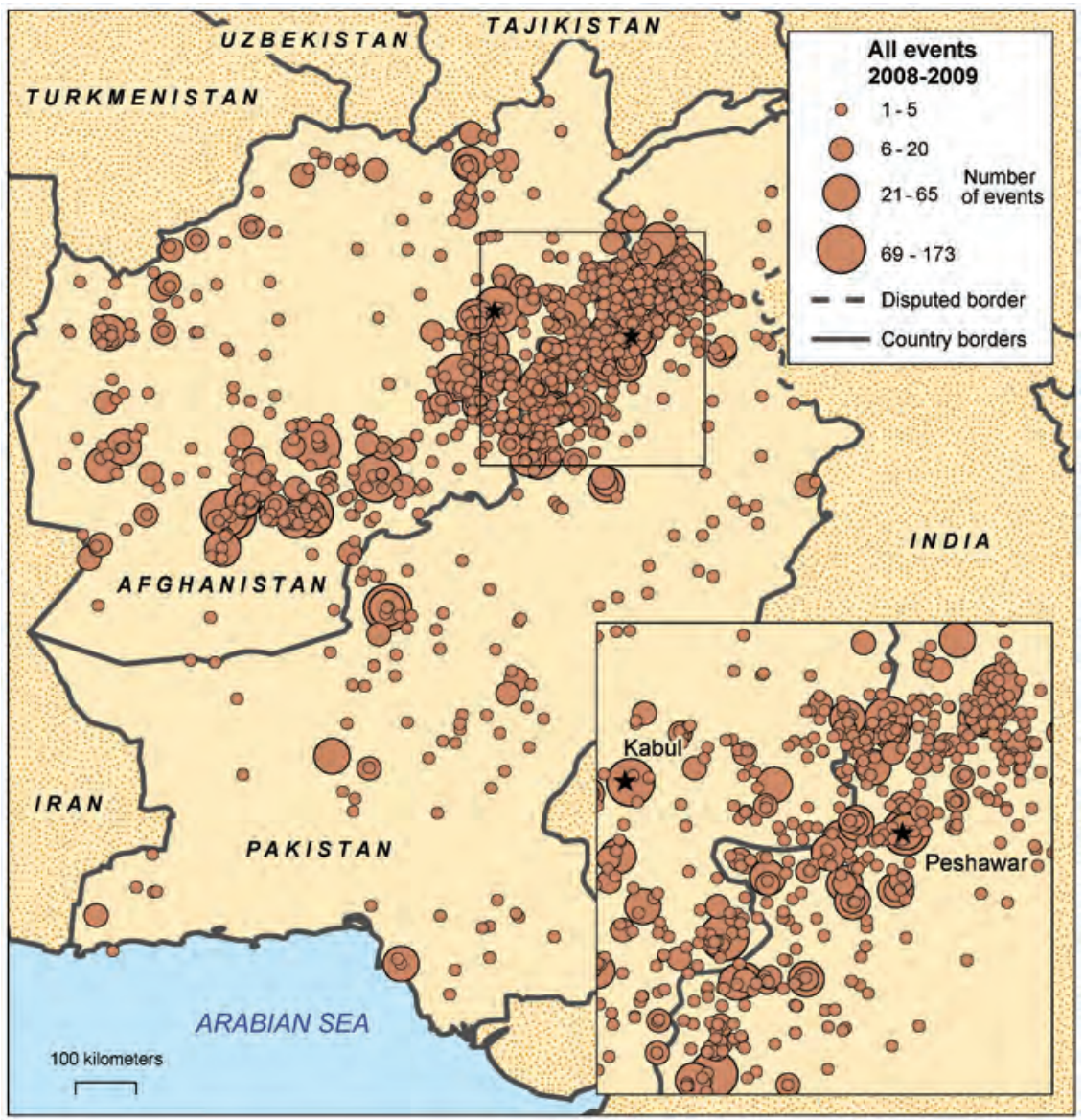

Fig. 2. Locations of all violent events in Afghanistan and Pakistan, 2008-2009.

1,649 classed as "insurgents." Since some of these events occur in the same locations, the number of locations varies from 368 for foreign forces, 622 for local forces, and 479 for insurgents. This typology allows us to dissect the events and detect trends according to which actors were primarily involved in the violent action.

Figures 3-5 show the spatial distribution and frequency for each type of event. Almost all of the foreign forces events take place in Afghanistan, although a few, primarily drone attacks and cross-border missiles launched from Afghanistan, extend over the border into Pakistan (Fig. 3). The local forces events are most prevalent in Pakistan along the Afghan border near Peshawar (Fig. 4). Insurgent violence has a wide geographic distribution, especially evident throughout Pakistan (Fig. 5). The maps provide clear evidence of both the wide spatial range of violence as well as its concentration in provinces near the Durand Line separating the two countries.

The three maps of Figure 6 present the quarterly (January-March, April-June, etc.) spatial distributional statistics (analogous to the univariate mean and standard deviation measures) for each of the three types of events (foreign, local, and insurgent). This space-time representation of violence provides a visual mechanism of assessing spatial trends in the data. 


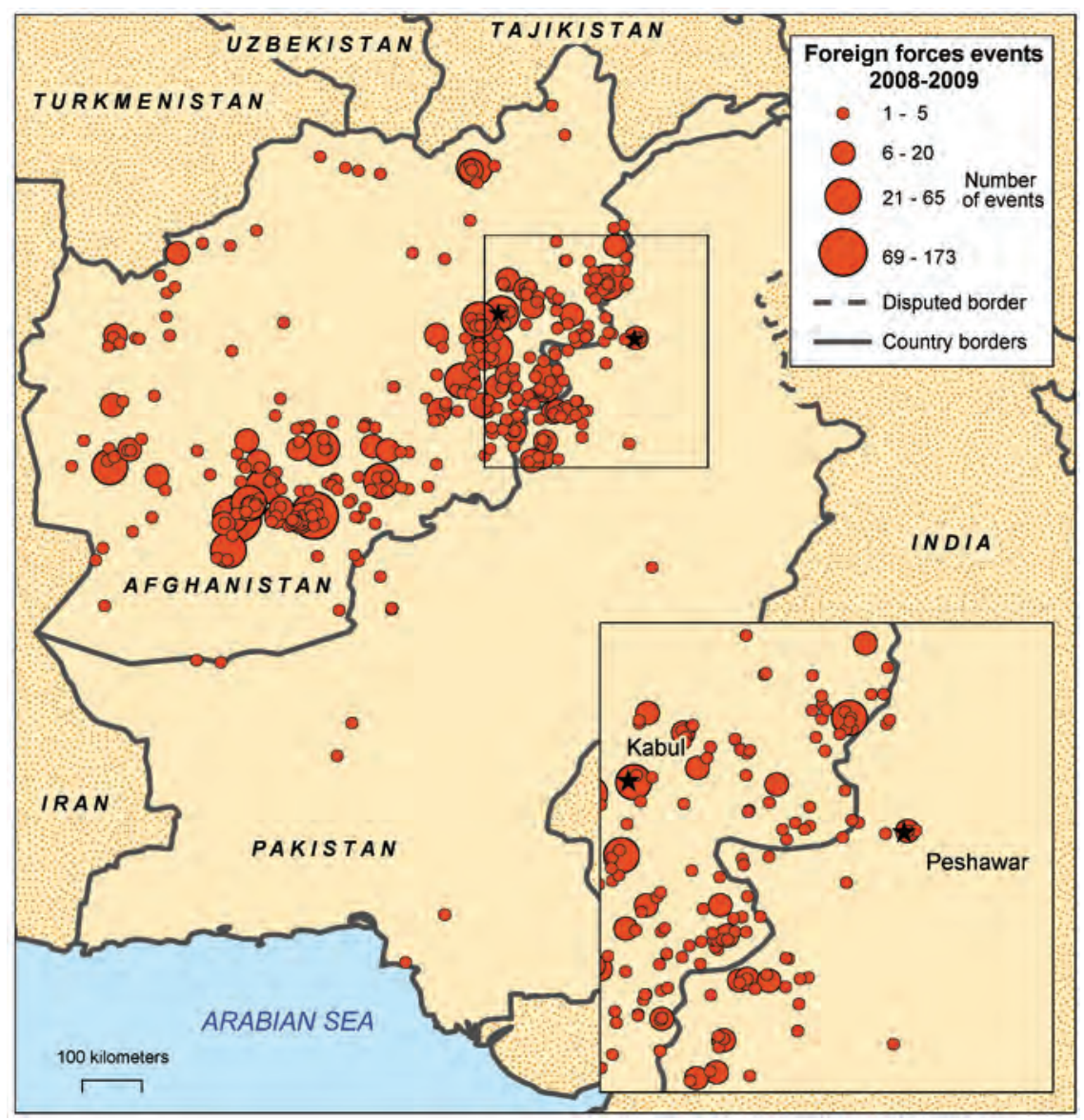

Fig. 3. Locations of violent events involving foreign forces in Afghanistan and Pakistan, 20082009.

A mean center is calculated by simply averaging all of the $\mathrm{x}$ - and $\mathrm{y}$-coordinates, respectively, for a set of point data and represents the locational center for those points. The standard deviational ellipses of Figure 6 are for one spatial standard deviation, meaning that two-thirds of events fall within the drawn ellipse (assuming the events are distributed normally over space).

For foreign forces events, the violence is consistently concentrated within Afghanistan along the border of Pakistan, although the last three quarters of 2009 reveal a shift northward in both the mean centers and standard ellipses. In Afghanistan, the distribution of foreign forces events maintains a relatively regular pattern. During the two years under investigation, the southern areas of Helmand and Kandahar provinces (see Fig. 1 for locations) remained a key focus for NATO and U.S. troops trying to disrupt insurgents' use of the opium trade for funding. Prominent Taliban figures, including Baitullah Meshud (killed by a drone missile in August 2009) and possibly Mullah Omar, resided in Quetta (Taliban Shura, 2009), in Pakistan's Baluchistan Province. While northern regions of the Tribal Areas receive close attention in the press, the south is gaining greater importance in the war as the conflict spreads 


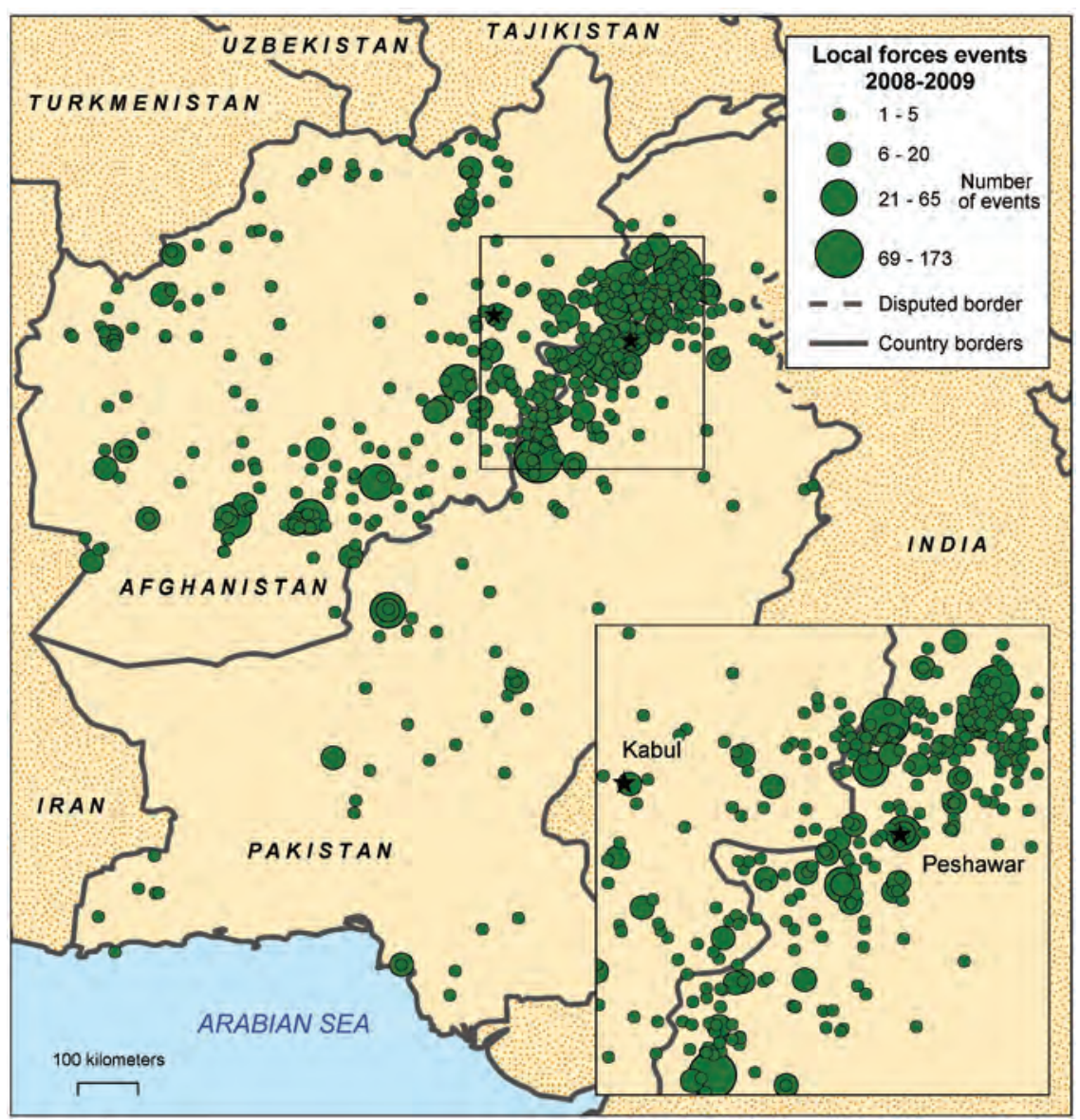

Fig. 4. Locations of violent events involving local forces in Afghanistan and Pakistan, 20082009.

in Pakistan. Overall, the concentration of foreign forces events over time demonstrates a nearly unchanged geographic pattern, though the ellipses are elongated for the later quarters. Compared with insurgent violence and the distribution of local forces activity in the other two maps, foreign forces are more geographically constrained, targeting the main locus of Taliban activity in the Kandahar-Kabul-Khyber triangle. Four provinces in the south and east of Afghanistan (Kandahar, Helmand, Paktika, and Konarha) have seen more than 3,000 violent events each in the six-year period, 2004-2009, as reported in the Wikileaks.org files. ${ }^{7}$

Overall, local forces events have a wider distribution than the foreign forces, especially during the first half of 2008, after which the distribution shifts northward and stabilizes, encompassing the key cities of Kabul, Peshawar, and Islamabad. In 2009 (series of green ellipses), it is clear that the activities of the two countries' national forces increasingly centered in and around the FATA and NWFP border regions, reflecting the shift in Pakistan's

${ }^{7}$ See the companion paper in this issue by O'Loughlin et al. (2010) for more regional details. 


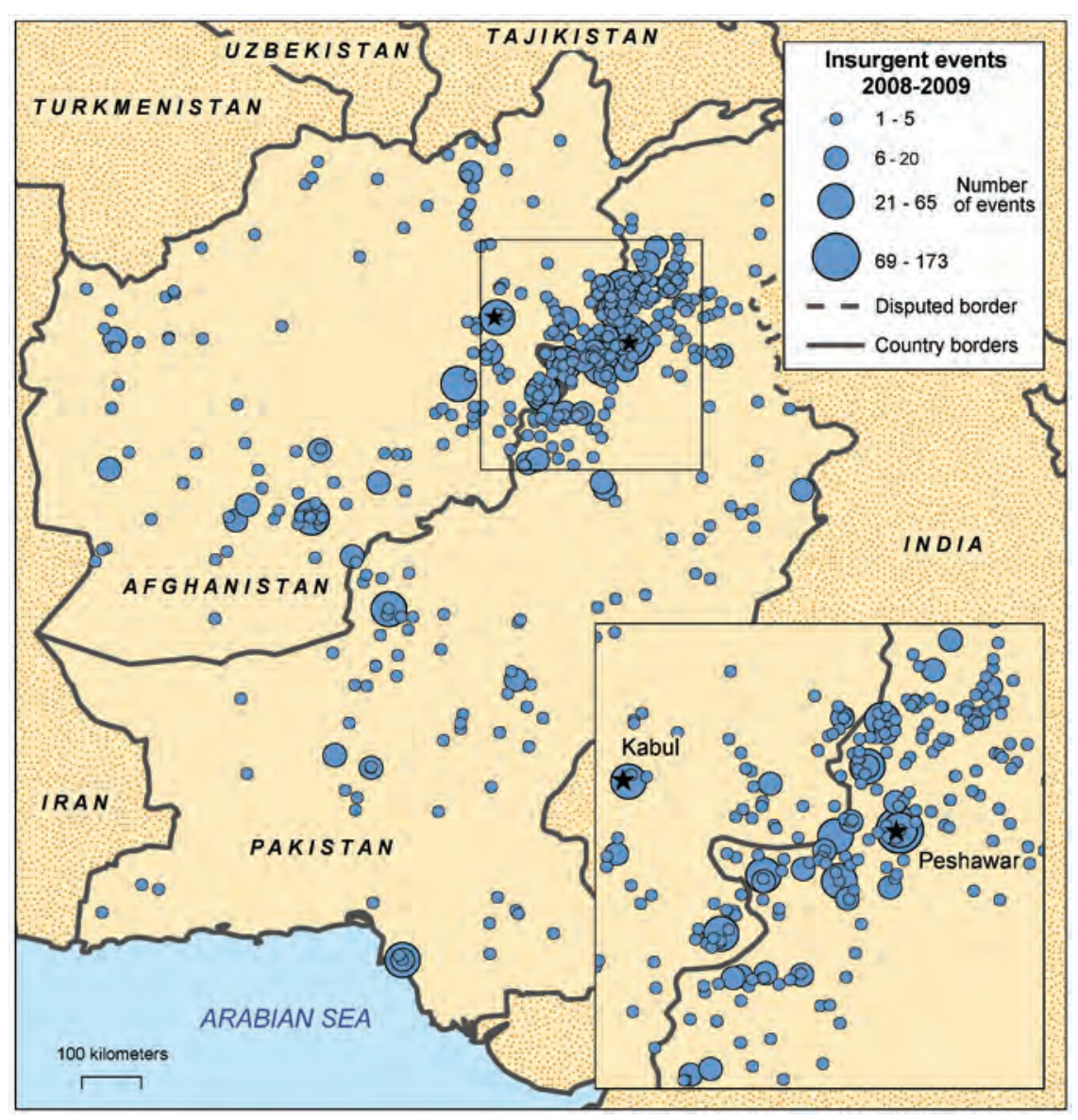

Fig. 5. Locations of violent events by insurgents in Afghanistan and Pakistan, 2008-2009.

policy to eliminating the Pakistani Taliban from its regional strongholds. The local forces' mean centers have shifted closer to the Pakistan border.

Insurgent events consistently exhibit the largest geographic spread, especially in early 2008. The position of the standard ellipses is oriented more on the north-south axis, with several mean centers over the border in Pakistan, reflecting the growing level of violence in this country. This distribution of events within Pakistan indicates that insurgent acts of violence have diffused significantly over the two-year time period. However, violence during much of 2008 represents the aftermath of presidential candidate Benazir Bhutto's assassination in late December 2007, when riots and antigovernment violence erupted throughout the country. An evident extension of insurgent violence during the third quarter of 2009 corresponds to Operation Sherdil ("Lionheart"), which has also been called the "Battle for Bajur."" The fighting began in August 2009 but lasted for longer than expected, into October (Fair and Jones, 2009). The events of the period also reflect the extremely violent August election in Afghanistan and a later lull in activity accompanied an October and November offer by President Karzai to insurgents to reach a peace agreement (Burns, 2008). 


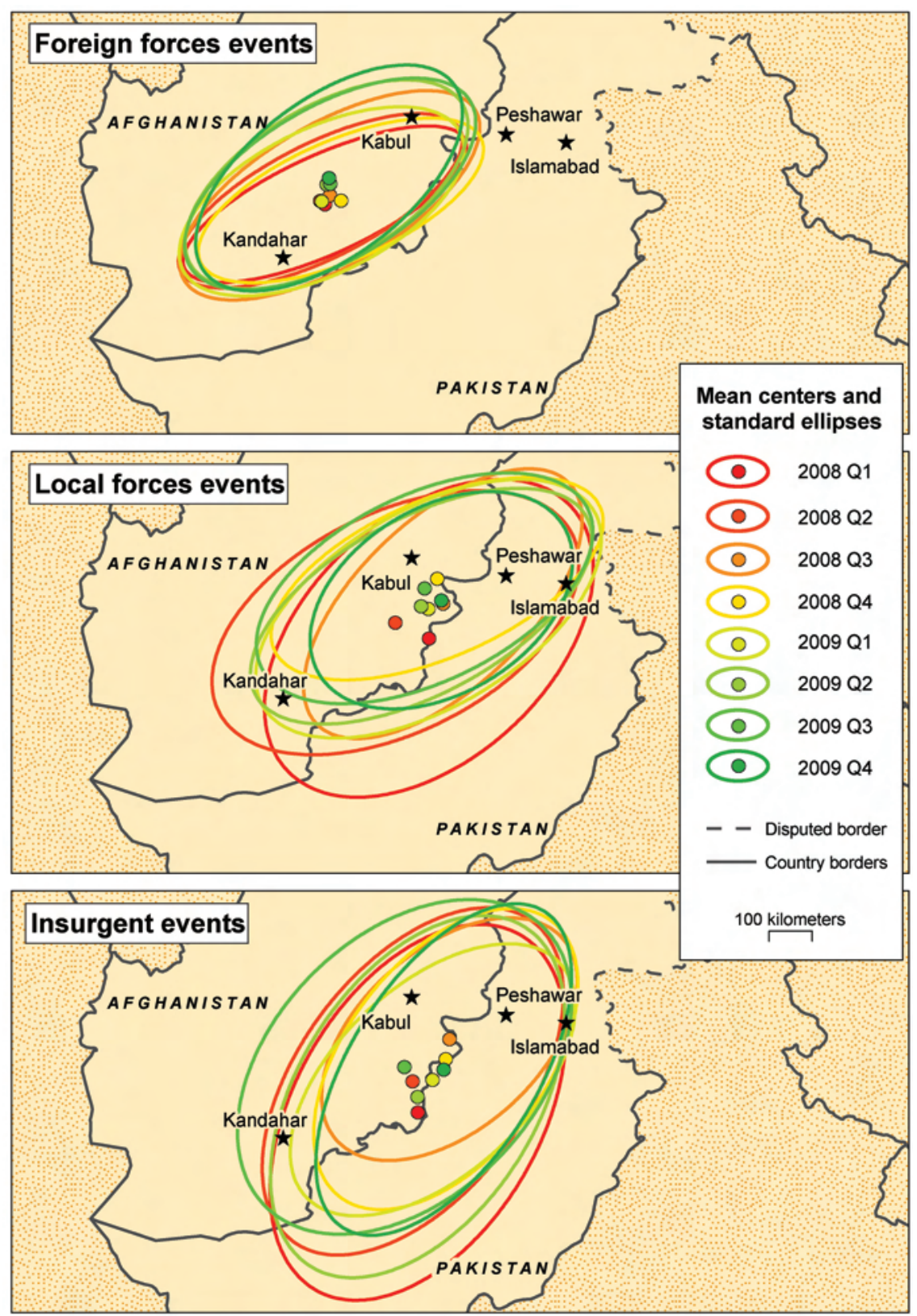

Fig. 6. Quarterly mean centers and standard ellipses by actor (foreign, local, and insurgents) in Afghanistan and Pakistan, 2008-2009.

To quantify changes in clustering of events over time, we use a modified Ripley's $K$ function (Getis and Franklin, 1987). Ripley's K compares the number of expected events within a given radius around each point to the observed number of events in that radius controlling for the size of the study area and overall density of points. For each radius, point patterns with $K$ 
Table 1. Number of Events and Maximum Radius (km) at Which Events Are More Clustered than Expected for Each Type of Violence

\begin{tabular}{lcccccc}
\hline \hline \multirow{2}{*}{ Quarter } & \multicolumn{2}{c}{ Foreign forces } & \multicolumn{2}{c}{ Local forces } & \multicolumn{2}{c}{ Insurgent } \\
& Events & Max. radius & Events & Max. radius & Events & Max. radius \\
\hline 2008 Q1 & 65 & 88.7 & 134 & 155.1 & 137 & 150.4 \\
2008 Q2 & 139 & 92.6 & 104 & 110.3 & 161 & 148.9 \\
2008 Q3 & 206 & 106.5 & 246 & 132.7 & 221 & 129.6 \\
2008 Q4 & 259 & 105.7 & 241 & 162.0 & 204 & 119.6 \\
2009 Q1 & 173 & 94.1 & 239 & 151.2 & 207 & 117.3 \\
2009 Q2 & 206 & 94.9 & 377 & 129.6 & 282 & 143.5 \\
2009 Q3 & 260 & 103.4 & 305 & 119.6 & 253 & 155.1 \\
2009 Q4 & 221 & 107.2 & 365 & 129.6 & 184 & 142.0 \\
\hline
\end{tabular}

function values that exceed the expected number are said to exhibit clustering, whereas lower than expected values indicate dispersion. To prevent bias in the estimate of $K$ at the boundaries of the study area, we used Ripley's isotropic edge correction (Ripley, 1988), which controls for portions of a given radius falling outside the study area. This edge correction method performs well when compared to other techniques under simulated conditions (Yamada and Rogerson, 2002). To account for non-stationarity (non-constant intensity) in the spatial distribution of violence, we use the modified inhomogeneous $K$ function, which takes the spatial inhomogeneity of the pattern into consideration (Baddeley et al., 2000). ${ }^{9}$

The quarterly results from this analysis (performed in R using spatstat 1.19-3) for each of the three actor categories are presented in Table 1. The total number of events for each quarter is shown in addition to the maximum radius at which the point pattern distribution is clustered. Foreign forces activity exhibits clustering for radii distances less than $110 \mathrm{~km}$, reflecting the more limited spatial distribution of these events, though in some time periods, local forces and insurgent events have maximum quarterly radii exceeding $150 \mathrm{~km}$. Higher numbers of events are associated with larger maximum clustering radii for foreign force events, but not for local forces. As the number of local forces events increased in Pakistan, they became more concentrated in North and South Waziristan in 2009, where they exhibit clustering at relatively small distances. The relationship between the number of events and their clustering is more inconsistent for the insurgent events.

The ACLED data also record the type of event, typically a battle event (between two armed groups) or violence against civilians, where civilians are unarmed. ${ }^{10}$ The number of violent events with civilian victims does not usually match the number of civilian deaths. One serious event may have many deaths and many relatively minor events cause only one death or injury each. Figure 7 shows the monthly trend in violence for Afghanistan and Pakistan. The graphs are cumulative, so the space between the two sets of lines is non-civilian violence.

\footnotetext{
${ }^{9}$ For an elaboration of the method, see Bailey and Gattrell (1995).

${ }^{10} \mathrm{We}$ should note that the number of civilian victims and events are likely to be undercounted because the foreign military (ISAF) and local governmental authorities are often the sources for the news reports on which the ACLED data are based. These agencies typically overstate the number of militants killed or injured in violent encounters and undercount civilian victims, who are numbered in the "unknown enemy" category of casualties.
} 


\section{A. Civilian and non-civilian Afghanistan violence}

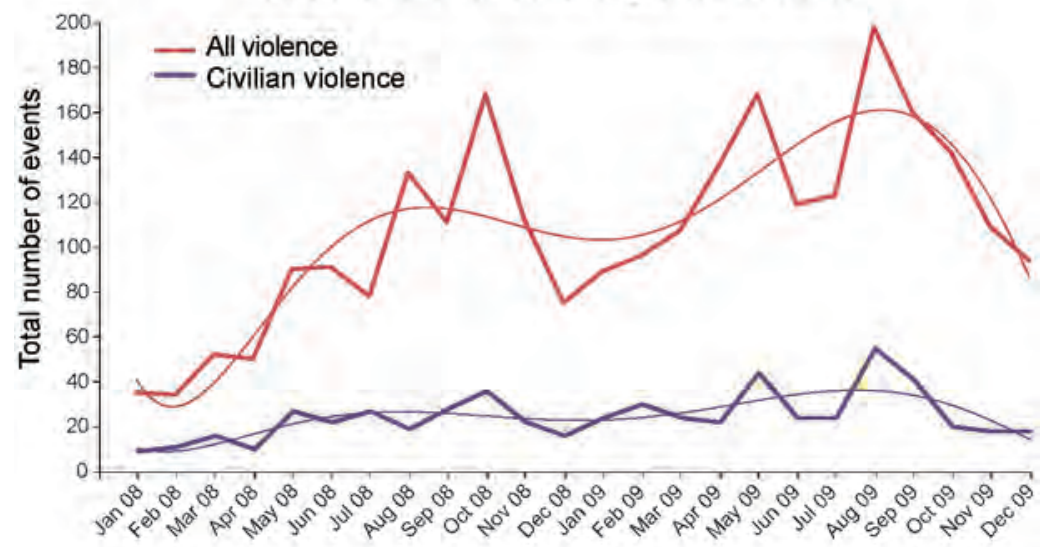

B. Civilian and non-civilian Pakistan violence

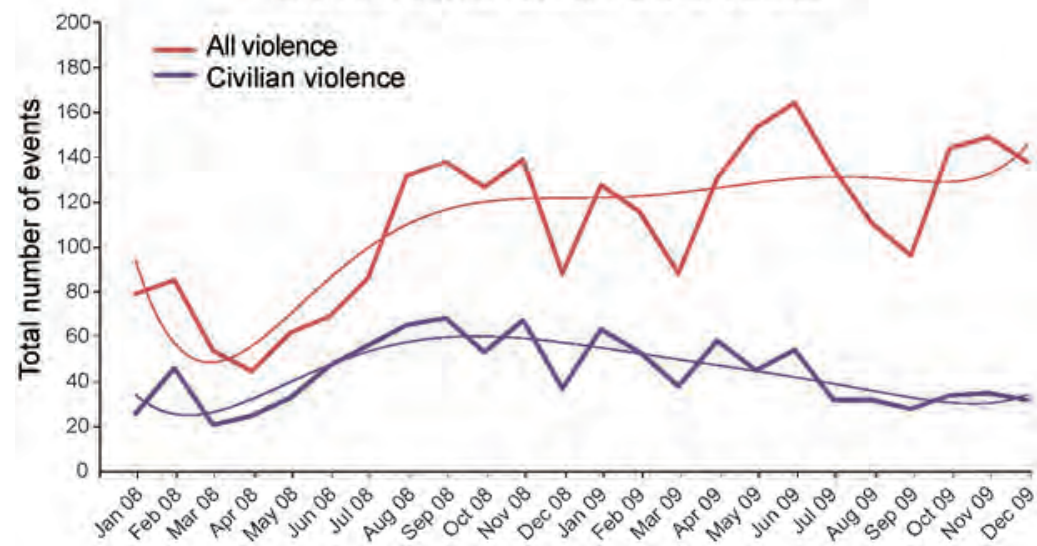

Fig. 7. Civilian and non-civilian violence in Afghanistan (A) and Pakistan (B), 2008-2009.

The smoothed lines are fifth degree fitted polynomials that highlight seasonal and long-term trends. In Afghanistan (Fig. 7A), a seasonal trend (higher in summer-early autumn and lower in winter) is evident for both civilian and total violence. An increasing long-term trend, especially for total violence, is also visible. The overall increase in violence in Afghanistan reflects renewed commitment of the U.S. to this theater of the "war on terror" after the reduction of violence in Iraq and increased troop commitments from the U.S. during the Obama presidency in 2009. Throughout the two-year period, a slow rise in attacks against civilians reflects a general trend noted earlier.

For Pakistan (Fig. 7B), the seasonal trend is less apparent, but the longer trends show both a flattening of the curve after Spring 2008 in violence against civilians and a general increase in all other violent events. A new cooperation agreement to fight the Taliban between the two countries followed meetings between Presidents Karzai of Afghanistan and Zardari of Pakistan in Istanbul in December 2008. However, the number of suicide and other attacks on civilians in public settings did not diminish. Many high-profile terrorist attacks are included in the civilian violence classification. Examples include a March 2009 attack on the Sri Lankan 


\section{A. Afghanistan violence by actor}

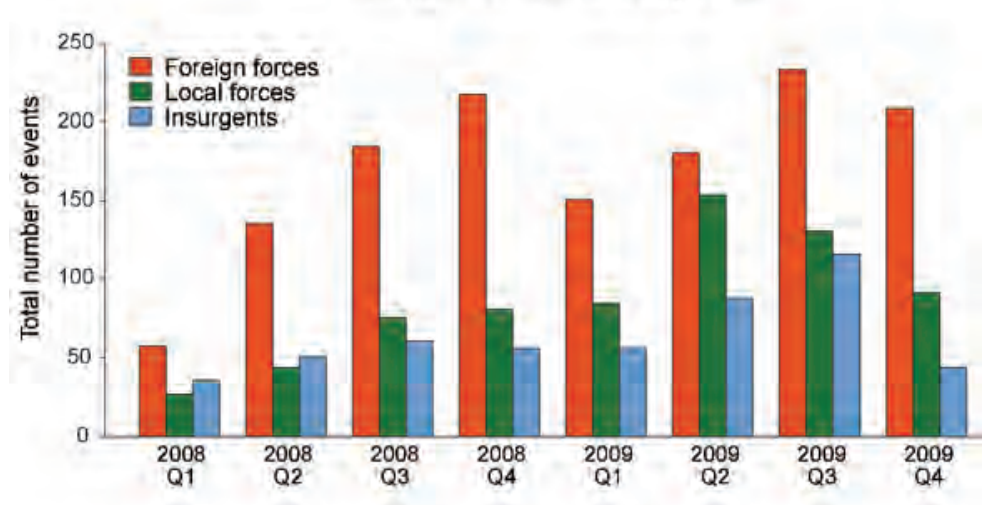

B. Pakistan violence by actor

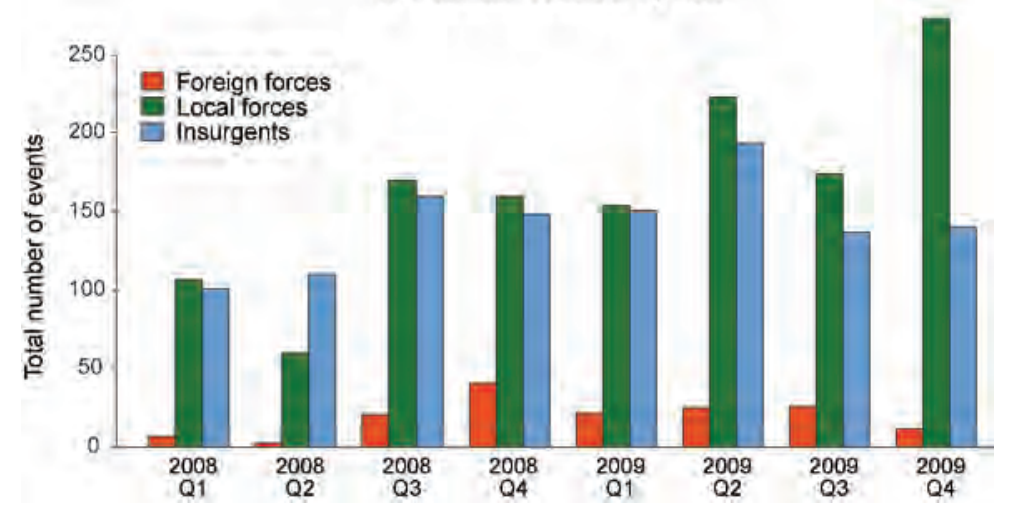

Fig. 8. Temporal distribution of violent events by actor (foreign, local, and insurgents) in Afghanistan (A) and Pakistan (B), 2008-2009.

cricket team in Lahore, the Marriott hotel bombing in Islamabad in September 2009, and an enormous suicide bombing in Peshawar that killed well over 100 people in October 2009. By the count in the "Pakistan Security Report" (PIPS, 2010), the number of attacks increased from 2,148 to 2,586 in 2009 and the number of deaths in these attacks jumped from 2,267 to 3,021 .

To smooth the considerable inter-monthly variation seen in Figure 7, the remainder of the graphs aggregate events by quarter for each of the three types of violence, showing how event intensity has changed by considering overall trends by country (Fig. 8), by rural/urban locations (Fig. 9), and by ruggedness of terrain (Fig. 10). As was evident previously in Figure 3 , the dominant role of foreign forces in Afghanistan is visible in Figure 8A, compared to Pakistan (Fig. 8B), whose foreign presence consists largely of drone attacks (see below). As in Figure 6, the seasonal trend by quarter is easily visible in Afghanistan but less so in Pakistan. Foreign forces events reached a peak in the fourth quarter of 2008. Immediately before leaving office, George Bush initiated a "quiet surge" of around 4,500 troops, and the violence trend illustrated in the graph may be a result of this policy (MacAskill, 2008). Although the trend reverses slightly near the end of 2009, our data reveal a spike in the number of events 
associated with Afghan army and police forces in spring 2009. This peak reflects an effort by NATO and U.S. troops to train local forces and encourage their engagement with the Taliban, a policy that was instituted in March 2009 as part of the Obama "new strategy" for confronting insurgents. ${ }^{11}$ The highest number of insurgent attacks during the entire study time frame took place in 2009's quarter 3, which encompasses the August presidential election, marred by a violence surge throughout the country.

In Pakistan, there is evidence of a rise in insurgent violence during the autumn of 2008, after which it remained high. In December 2007, a coalition (Tehrik-i-Taliban, Pakistan TTP) was formed to unite militants to attack the Pakistani state, not just U.S. and NATO forces in Afghanistan (Fishman, 2010). This increase encouraged the government to state a timeline for introducing sharia law in the Swat Valley during early 2009 (Walsh, 2009; Brown and Mustafa, 2010). While foreign forces events are rare in Pakistan, the highest number of these events took place in the fourth quarter of 2008, which was also the most violent month for drone attacks (see below). The BBC reported in July 2010 that 279 persons were killed in South Waziristan and 386 in North Waziristan by drone missiles between January 2009 and July 2010 (Mapping, 2010). ${ }^{12}$ In the same period, more than 2,500 people were killed in militant attacks throughout the country; the last quarter of 2009 extending into January 2010 was the peak for both drone and militant attacks, corresponding to the major effort of the Pakistani military to take control of South Waziristan (ibid.). Evidence of a shift in Pakistan's focus after years of criticism that the armed forces have not been effectively fighting insurgents came in 2009, which saw a big increase in Pakistani government forces activity against the various insurgent groups in the Tribal Areas and in NWFP (Fishman, 2010).

To explore trends in violence by urban and rural areas, we first partition our study area into urban and rural categories. Cities are important arenas of conflict because of their symbolic significance (Esser, 2004). Though scores of definitions for urban environments exist (McIntyre et al., 2000), our goal is to identify built-up areas with a high concentration of residents, thus categorizing these places from surrounding rural areas. We explored multiple databases for attaining this identification in the absence of reliable and recent census data. Shortcomings abound in the main sources, including the Landscan population grid (Oak Ridge National Laboratory, 2008), populated places polygons from the Digital Chart of the World (DCW) (Danko, 1992), and the Global Rural-Urban Mapping Project (GRUMP) (CIESIN/IFPRI/CIAT, 2005). For each of these datasets, we compared the identified urban areas visually to fine-resolution imagery available in Google Earth.

The Landscan data tend to overestimate population in agricultural areas and along roads because of its methodology of spatially allocating census population numbers. Despite adjusting the population density thresholds separately for Afghanistan and Pakistan using the Landscan data, we were not able to generate a satisfactory urban representation. The DCW data were also problematic inasmuch as the "populated places" polygons were handdrawn during the 1960s and 1970s by the U.S. Defense Mapping Agency and typically were drawn inconsistently in terms of minimum urban size, and additionally the urban areas have grown during the last several decades. The GRUMP data matched current urban delineations most closely. These data rely primarily on nighttime lights satellite imagery from the Defense Meteorological Satellite Program (DMSP) Operational Linescan System (OLS) recorded in 1994-1995 (Elvidge et al., 2001).

\footnotetext{
${ }^{11}$ This new strategy took place around the time that General McChrystal replaced General McKiernan as director of NATO forces.

${ }^{12} \mathrm{~A}$ further 81 were killed elsewhere in the country.
} 


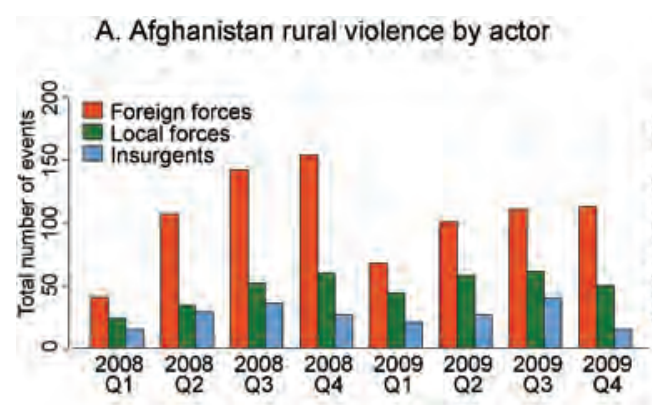

B. Afghanistan urban violence by actor

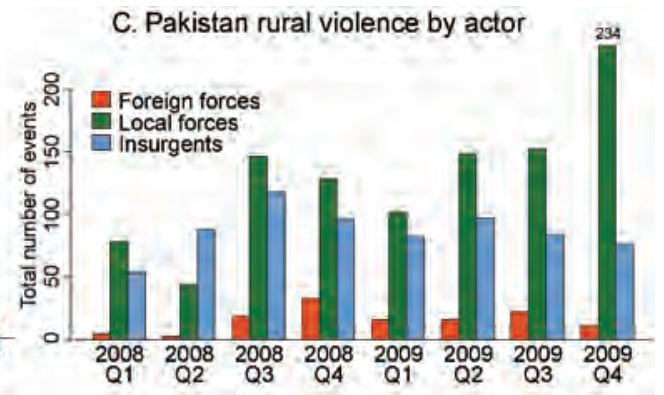

D. Pakistan urban violence by actor

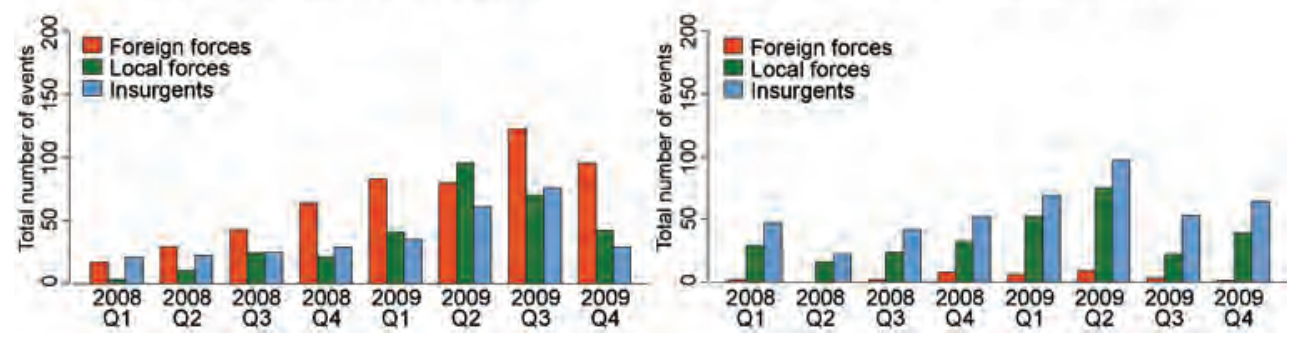

Fig. 9. Distribution of violence by type of settlement and country, 2008-2009.

To account for changes in human settlement since the mid-1990s GRUMP data, we used 2008 DMSP-OLS data (NOAA/USAF, 2009) to define the urban area features. The nighttime lights imagery consists of an annual composite of cloud-free and moon-free scenes with 6-bit radiometric resolution, pixel values ranging from a 0 (dark) to 63 (bright) digital number (DN). To extract urban features, we set separate threshold values for Afghanistan and Pakistan. This takes into account the differential levels of built areas and wealth between the countries, because nighttime light intensity is strongly associated with socioeconomic status (Doll et al., 2000; Elvidge et al., 1997, 2009). For Afghanistan, we used a minimum pixel value of $6 \mathrm{DN}$, and for Pakistan, $22 \mathrm{DN}$. These values were selected using an iterative process that compared urban area definitions to fine-resolution Google Earth imagery. These threshold values reflect, in part, the wealth disparity between Afghanistan and Pakistan. In 2008, Afghanistan's GNI/capita was estimated at $\$ 370$ and $\$ 950$ across the border in Pakistan (World Bank, 2009).

The results from this analysis show that most of the violence in both Afghanistan and Pakistan occurs in rural areas (Fig. 9) ${ }^{13}$ For Afghanistan, there is a noticeable trend of increasing violence in urban areas for foreign forces, while in Pakistan, the recent increase in violence is mostly a rural phenomenon. In Afghanistan, the overall rise in rural violence supports Kilcullen's $(2009$, p. 47) claim that violence spread throughout the country during 2008; the foreign forces response to that violence was largely in rural environs. The notable decline in the presence of foreign forces in rural areas in late 2009 reflects the shifting policies of the Obama administration and the closure of some forward operating bases (FOBs). By contrast, the presence of foreign troops in urban areas illustrates a rather uniform pattern over time, due to the importance attached to these strategic centers and their control by ISAF forces.

\footnotetext{
${ }^{13}$ Our definition of urban excludes small towns and villages.
} 
Pakistan's violence takes place predominantly in rural areas, especially in the Tribal Areas. Interestingly, however, insurgent violence dominates urban areas, in dramatic contrast to patterns of Afghan violence. By the BBC count, militants attacked (mostly with bombings) Pakistani locations 144 times between January 2009 and June 2010, and caused more than 600 deaths in four cities (Peshawar, Lahore, Khyber, and Rawalpindi; Mapping, 2010) ${ }^{14}$ An increase in the activity of local forces in Pakistan during 2009 reflects the fact that insurgents gained almost complete control over the Tribal Areas and NWFP during $2008^{15}$ and the renewed attempt by Pakistani forces to take control of the border provinces in the following year.

We further explore the trends in violence by categorizing each event according to roughness/steepness of terrain. This examines the argument in recent research concerning the use of rugged terrain by insurgents as a haven of protection and launch-pad for attacks (Hegre and Sambanis, 2006) and tests a more general geographic model of insurgency from McColl (1969). Buhaug et al. (2009) show that conflicts located near remote international borders (as well as those far from the capital and in regions with valuable resources) last longer than other civil conflicts. If insurgents use more inaccessible terrain to organize, replenish supplies, maintain bases, and control a local population, they develop the capability of carrying out attacks in cities and towns relatively close to these regions. The development of bases in difficult terrain is the focus of our analysis because government and allied forces attacking the insurgents must penetrate mountainous areas to permanently remove the insurgent headquarters. We characterize terrain according to three categories: flat (less than $4^{\circ}$ in slope); hilly (from 4 up to $8^{\circ}$ in slope); steep (greater than or equal to $8^{\circ}$ in slope). The slope data are derived from $1 \mathrm{~km}$ pixel digital elevation data collected on the Shuttle Radar Topography Mission in 2000 (USGS, 2004). The original elevation data were projected to Universal Transverse Mercator (UTM) zone $41 \mathrm{~N}$ and used to calculate slope (in degrees) for the study area. To assign a slope value to each event, a circle of radius $2.5 \mathrm{~km}$ was constructed around each georeference, and the average slope of all pixels within the circle (typically 18-20 pixels) was assigned to the event, providing a representative measure of terrain for each event.

The quarterly trends in violence for each of the slope categories in Afghanistan and Pakistan are shown in Figure 10. In both countries, most of the events occur in flat terrain, especially noticeable in Afghanistan. Such a pattern is expected considering the importance of the ISAF/U.S. campaign in Helmand and Kandahar provinces in the south in addition to operations in Paktika, Paktia, Nangrahar, and Kunar provinces along the northern border with Pakistan. The seasonal trends (more activity in the warmer months) observed in the graphs above are still visible in Afghanistan for all terrain categories, but they are also now visible in Figure 10 for Pakistan for hilly and steep terrain, where the rigors of fighting in inclement weather are magnified. Especially noteworthy are the recent upticks in Pakistan government forces activity concentrated in hilly and steep terrain (the Tribal Areas and NWFP). Our results both support and challenge the relationship between inaccessible terrain and propensity for conflict that is often found in the strategic studies, political science, and economics literatures, and demands a more careful look at the political dynamics and social mechanisms than can be captured by simplistic national-scale metrics. Consider Johnson and Mason (2008, p. 60) who argue that "insurgency has always come from the hills." While we find that the majority of fighting occurs in relatively flat rather than the steeper terrain, we cannot be sure from

\footnotetext{
${ }^{14}$ See also Mustafa and Brown (2010) on the Taliban's targeted attacks on public places in Pakistan.

${ }^{15}$ Note the increase throughout 2008, and the largest spike in the entire period during the third quarter of 2008 (Fig. 9C).
} 

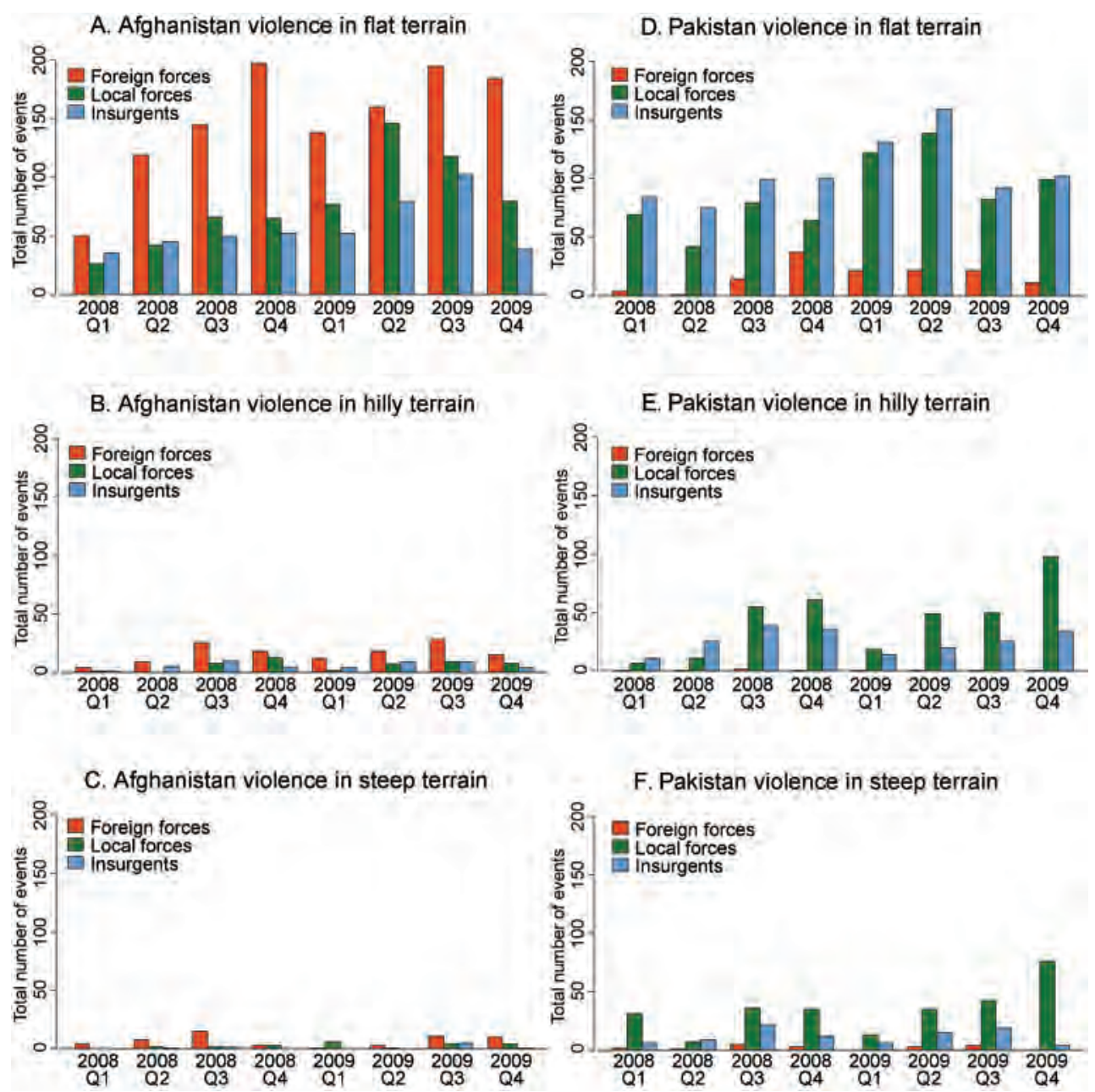

Fig. 10. Distribution of violence by slope categories in Afghanistan and Pakistan, 2008-2009.

our data whether the fighters organized in the mountains. Insurgent violence is increasingly evident in urban areas of Pakistan, for instance.

Our spatial and temporal analysis of the distribution of violence in the Afghanistan-Pakistan theater of conflict shows both seasonal and geographically specific elements. Although a two-year period is insufficient to detect long-term trends, it is evident from the maps and graphs that the conflict is intensifying, that insurgent activity is spreading, and that the spatial focus of local and foreign forces is still strongly oriented to the border area and adjoining provinces on both sides of the Durand Line.

\section{Question 2: Where Are the Specific Hotspots (Clusters) of Violence in Afghanistan and Pakistan?}

This analytical section explores the event data further by looking for trends in violence according to specific administrative borders and ethnic regions to detect more specifically 
A. Afghanistan violence within $100 \mathrm{~km}$ of border

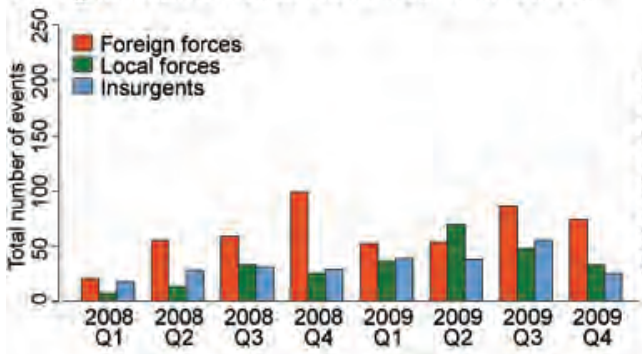

B. Afghanistan violence beyond $100 \mathrm{~km}$ of border

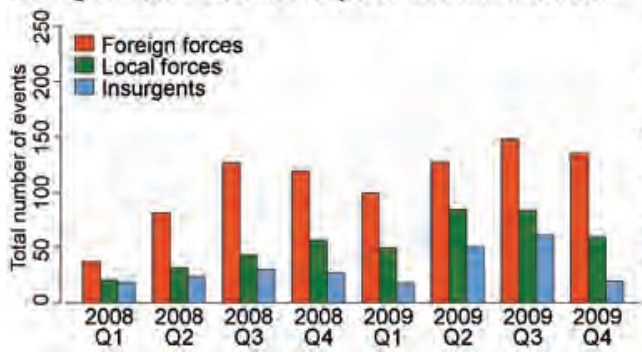

C. Pakistan violence within $100 \mathrm{~km}$ of border

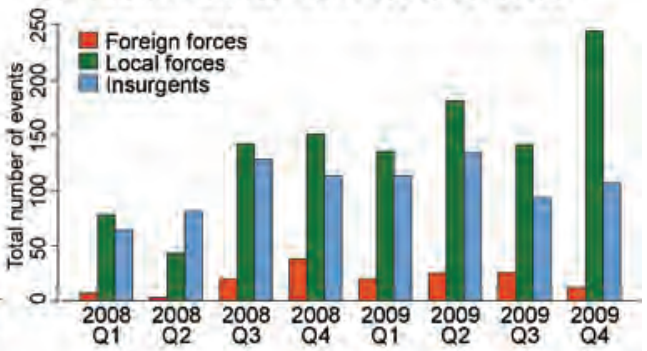

Fig. 11. Distribution of conflict in border and non-border areas in Afghanistan and Pakistan, 20082009.

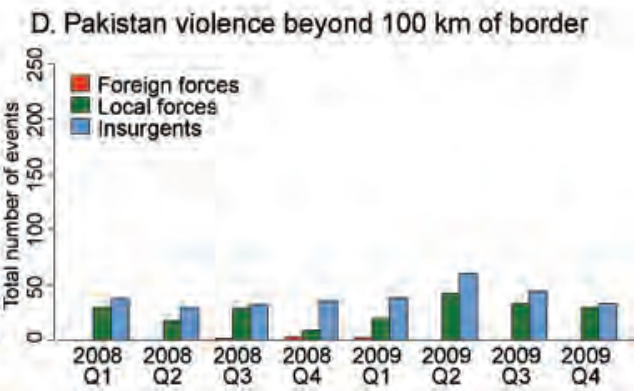

places where violence is clustered in space and time. The first analysis extracts the quarterly trends by actor for areas near the Afghan/Pakistani border and compares them with trends for areas away from the border. Polygon data from the Environmental Systems Research Institute (ESRI, 2008) were used to define the administrative borders. We used a distance threshold of $100 \mathrm{~km}$ from the Afghan/Pakistan border to categorize events.

The spatial distributions and standard ellipse maps presented earlier revealed an overall concentration of violence along the Afghanistan/Pakistan border. An analysis at finer resolution reveals substantially different patterns between Afghanistan and Pakistan (Fig. 11). In Afghanistan, most of the events involving foreign forces occur away from the border, while insurgent activity is a greater proportion of all violence in areas near the border (Figs. 11A and 11B). During much of 2008, insurgent violence occurred at a rate higher than conflict involving local forces (excluding Q3). During each quarter in areas distant from the border, the proportion of events across the three categories is uniform: foreign forces events are greatest, followed by Afghan police and army events and insurgent events, respectively. Diverging from this trend, the ratio of violent events across the actor categories near the border fluctuates considerably, suggesting unstable conflict dynamics in border areas.

While all regions of Pakistan have now experienced attacks, the intensity of violence aggregated by quarter is overwhelmingly concentrated near the border (Figs. 11C and 11D). This lends support to the contagion model of conflict diffusion (O'Loughlin and Anselin, 1991), an over-spill from Afghanistan into Pakistan with the border region as a conduit. The Pakistani administration's effort in 2009 to quell a Taliban insurgency is notable in the increasing number of national army and police force events within border regions including the Tribal Areas. Almost all foreign forces involvement in Pakistan takes place within the border region, consisting primarily of drone strikes. 

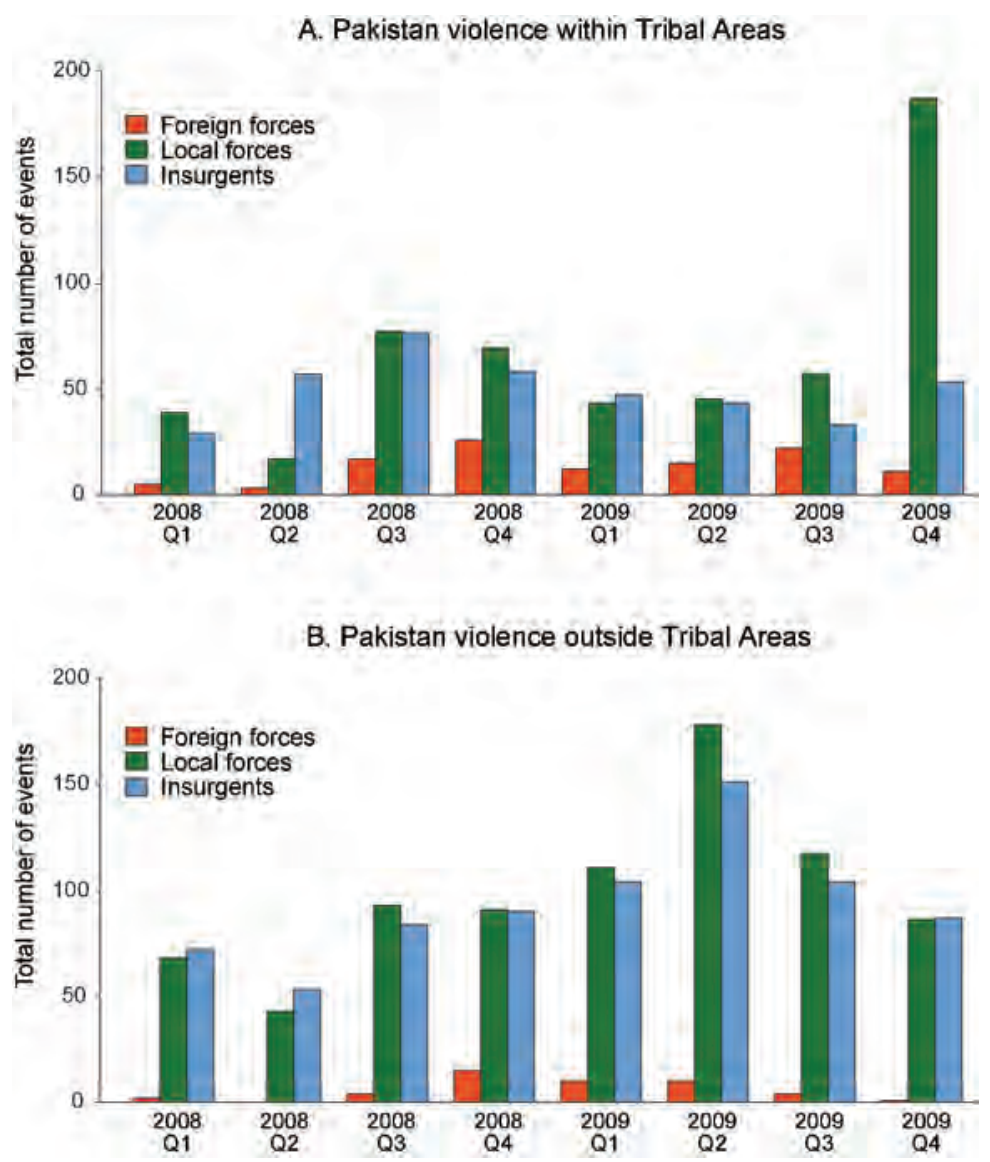

Fig. 12. Distribution of violence in FATA regions of Pakistan (A) and in non-FATA regions (B), 2008-2009.

We can delve further into the violence in Pakistan by looking at the event trends in the Federally Administered Tribal Areas (FATA). This region consists of seven tribal areas and six frontier regions within Pakistan, a region in which the Pakistani Taliban is highly active. We again use the ESRI data to define the FATA borders, modified to include the Peshawar and Kohat frontier regions whose boundaries changed after the ESRI data were generated.

Our sub-national analysis shows that most violent events in Pakistan occur outside of FATA, with the notable exception of foreign forces events (drone attacks) which concentrate within the Tribal Areas (Fig. 12). Most revealing is the large increase in local forces activity during the fourth quarter of 2009. This shows a more detailed picture of the recent increase in violence in Pakistan seen in the prior graphs. Not only is the large increase in local forces activity occurring in rural, hilly/steep areas near the border, it is more specifically occurring in the FATA district. This reflects the policy shift of the new Pakistani government after the election of Asif Ali Zardari in 2007 and an agreement to cooperate with the U.S./NATO governments in trying to end Taliban-allied control of the tribal areas in Pakistan. The rise in local forces activity during 2009 outside of the Tribal Areas is associated with the high-profile terrorist attacks noted earlier, affecting Rawalpindi, Peshawar, Lahore, and other major cities. 


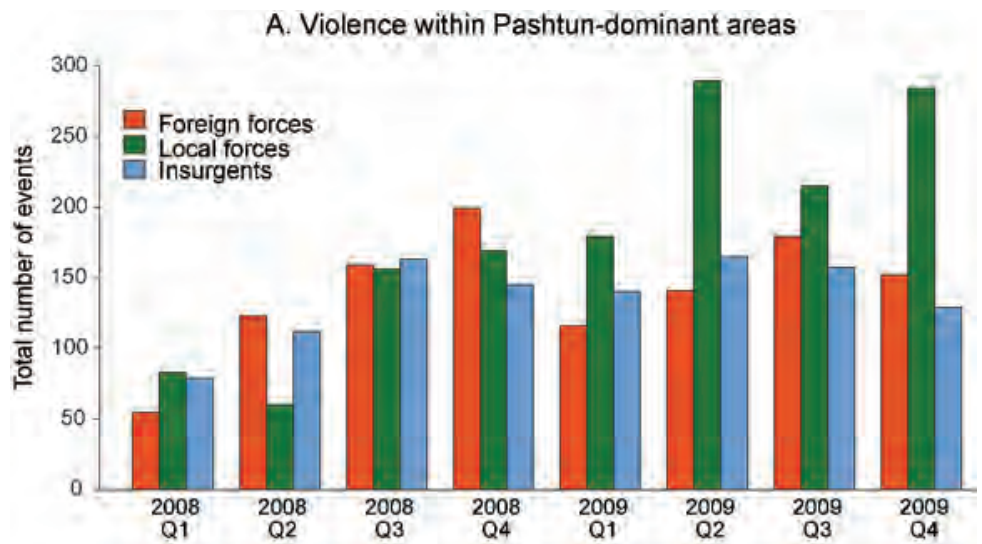

B. Violence outside Pashtun-dominant areas

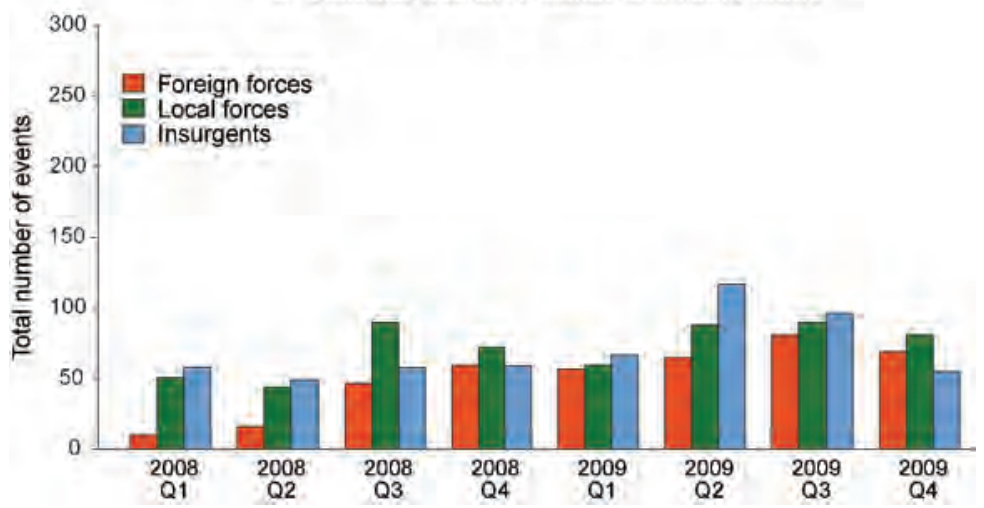

Fig. 13. Distribution of violence within (A) and outside (B) Pashtun-majority areas in Afghanistan and Pakistan, 2008-2009.

We also aggregated conflict event trends according to Pashtun ethnicity, the dominant group of the region often implicated in the violence. Ethnically Pashtun areas were designated using the Geo-Referencing of Ethnic Groups (GREG) data, which were digitized from the maps published in the early 1960s in a Soviet atlas, Atlas Narodov Mira (Bruk and Apenchenko, 1964; Weidmann, et al., 2010). The Pashtun region in our study area stretches from the border of Iran west of Lashkar Gah through the northern portions of Helmand and Kandahar provinces and extends northward through all of FATA and much of the NorthWest Frontier Province. The cities of Ghazni, Gardez, Kabul, Jalalabad, and Peshawar are all included in this region (Fig. 1). ${ }^{16}$

The distribution of events within and beyond Pashtun-dominated areas show that most of the violence is occurring within the Pashtun areas-71.0 percent in 2008, and 69.9 percent in 2009 (Fig. 13). Recent increase in local force activity is most evident in Pashtun areas on the Pakistani side of the Durand Line. The idea that violence in Afghanistan and in Pakistan's border region can be characterized as a "Pashtun insurgency" is widely promulgated. Johnson and Mason (2008, p. 73) suggest, for instance, that "the United States has no

\footnotetext{
${ }^{16}$ See also Figure 1 in Mustafa and Brown (2010, this issue) for the Pashtun distribution in Pakistan.
} 
long-term security problems with the Baluchis, the Chitralis, the Tajiks, the Nuristanis, or any of the myriad tribal groups along the Pakistan-Afghanistan border, save one: the Pashtuns.” In contrast to this general opinion, Acharya et al. $(2009$, p. 97) suggest that money and trade ties keep the Pakistani Taliban together as much as co-ethnic bonds. While the ethnicity of every individual actor is unknown to the data coders, broad patterns of violence concentration in the Pashtun areas, the traditional base of the Taliban, are clearly visible in our maps and graphs.

To identify specific areas of violence or hotspots, we used the SaTScan software to detect clusters (Kulldorff and Information Management Services, 2009). SaTScan uses a space-time scan statistic to detect unusually concentrated events (Kulldorff et al., 2005). This technique has been applied successfully to detect violent event clusters in the North Caucasus of Russia (O'Loughlin and Witmer, 2010) and is widely used in the study of disease distributions and in pinpointing crime hotspots. The technique constructs space-time cylinders up to the maximum user-defined limits, where the cylinder radius represents ground distance and its height is the length of the cluster in days. We used a maximum cluster radius of $50 \mathrm{~km}$ and a maximum height or length of 6 weeks. The algorithm computes the number of events within the varioussized space-time cylinders and compares that number to the expected number of events if they were distributed uniformly over space and time. Cylinders with a higher number of events than expected are tested against 999 Monte Carlo simulations to determine if the clusters are statistically different from a random distribution. We retain only those space-time clusters that have less than a 5 percent chance of occurring by chance. This type of spatial statistical analysis is capable of detecting clusters of violence not readily apparent from other mapping or categorical analyses.

The "hotspot" analysis results for four half-year periods are shown in Figure 14. The clusters are colored to reflect the duration of the clusters in periods of one week, one to three weeks, and three to six weeks, respectively. These maps indicate that the most intense space-time hotspots are generally along the Afghan/Pakistan border. In the first half of 2008, a hotspot spans the border in the southern portion of Pakistan's Tribal Areas south of the Afghan city of Gardez. This violence marks a period of insurgent advances within North and South Waziristan ( 2 of the 7 Tribal Agencies). During the second half of 2008, there are several substantial (both spatially and temporally) clusters of conflict activity south and west of Peshawar, focused on the strategic road through the Khyber Agency, a pathway for supply lines to NATO and U.S. troops. On December 13, 2008, the BBC, summarizing reports from Pakistani news agencies, noted a dramatic spike in attacks on convoys in Pishtakhara and Hazarkhwani that corresponds with this fighting (BBC, 2008). In southern areas surrounding the cities of Kandahar and Lashkar Gah (the capital of Helmand Province), an increasingly concentrated pattern of violence combined the effect of the Sarposa prison break (hundreds of fighters were freed) in Kandahar city in mid-June 2009 and the simultaneous ramping up of ISAF and Afghan government force activity in these key provinces

The hotspots map highlights surges in violence during 2009, such as the April-May 2009 Swat Valley offensive northeast of Peshawar and the push to remove the Taliban from Kunduz in November 2009. Fighting on the Pakistan side of the Tribal Areas border picked up in 2009 , both as a cause and a consequence of increased drone missile strikes. Obvious clustering in the second half of 2009 may also be the effect of renewed military commitment in the area by the Zardari administration. Interestingly, the 2009 patterns of violence in Afghanistan are characterized by less spatial and temporal clustering during 2008. As we have seen earlier, 2009 was a more violent year, but the distribution of violence across space within the country varied from that occurring in 2008 and was less concentrated. This significant change is a result of new policies beginning with President Obama's inauguration, a renewed attempt 


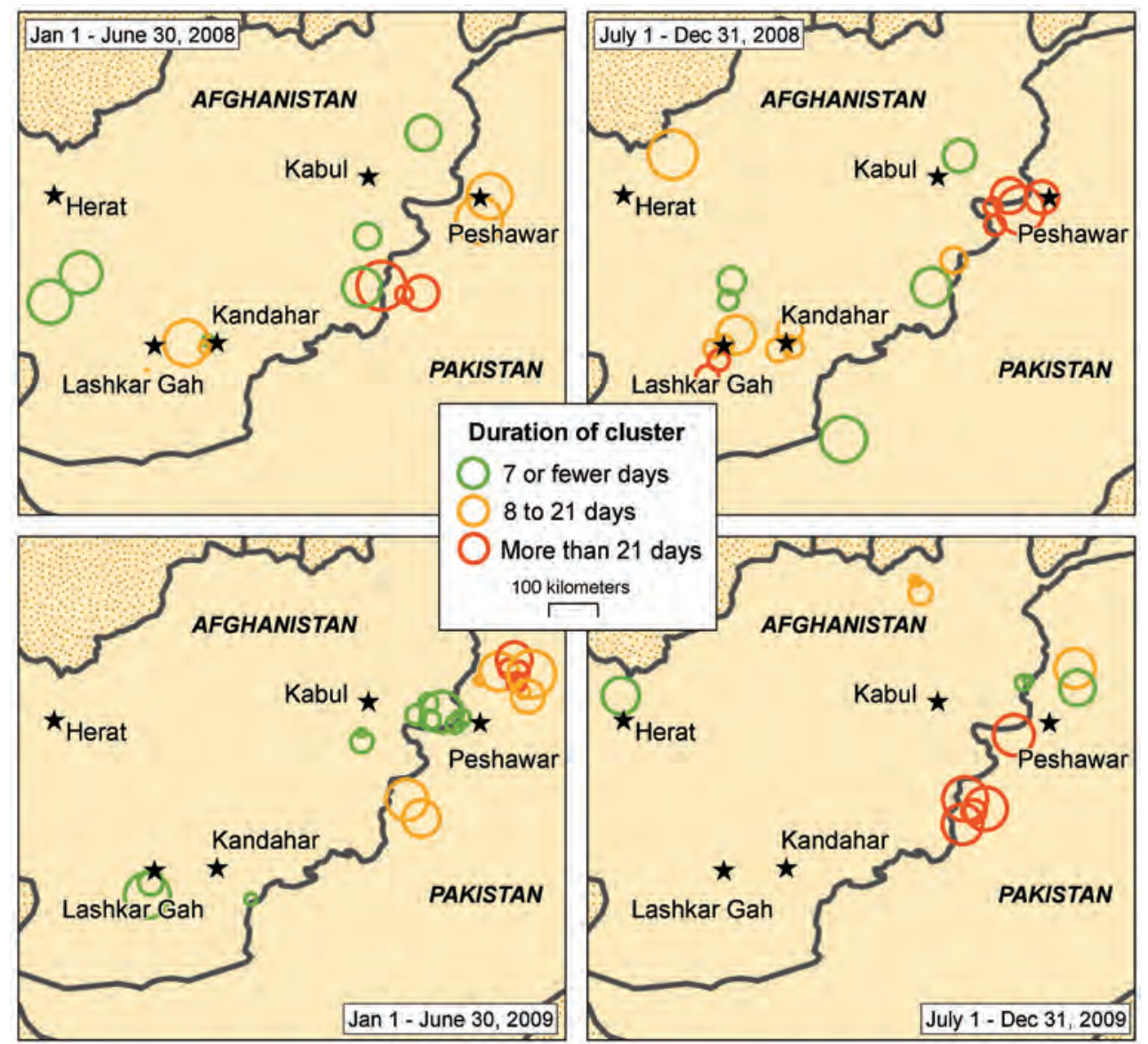

Fig. 14. Space-time clusters of violence by six-month periods in Afghanistan and Pakistan, 20082009.

to take military control of the Tribal Areas, and a ramping up of the insurgency beyond its traditional locations.

Question 3: What Are the Locational Changes and Temporal Trends of Drone Missile Attacks in Pakistan?

The final question motivating our research specifically considers 2008/2009 spatial and temporal patterns in drone missile attacks in Pakistan. We extracted the same ACLED data described above that specifically mentioned these attacks in the violence account, and checked the list against the New America Foundation database (2010). The Obama administration has come to rely heavily on the use of drones in Pakistan to target important Taliban leaders, and although of dubious legal justification and highly unpopular in the region and in Pakistan as a whole ${ }^{17}$ the policy shows no sign of changing. This increase in drone strikes over the Bush

${ }^{17}$ A 2009 al-Jazeera-Gallup poll found that 64 percent of Pakistanis oppose U.S. drone strikes in the FATA (Fishman, 2010, p. 10). 


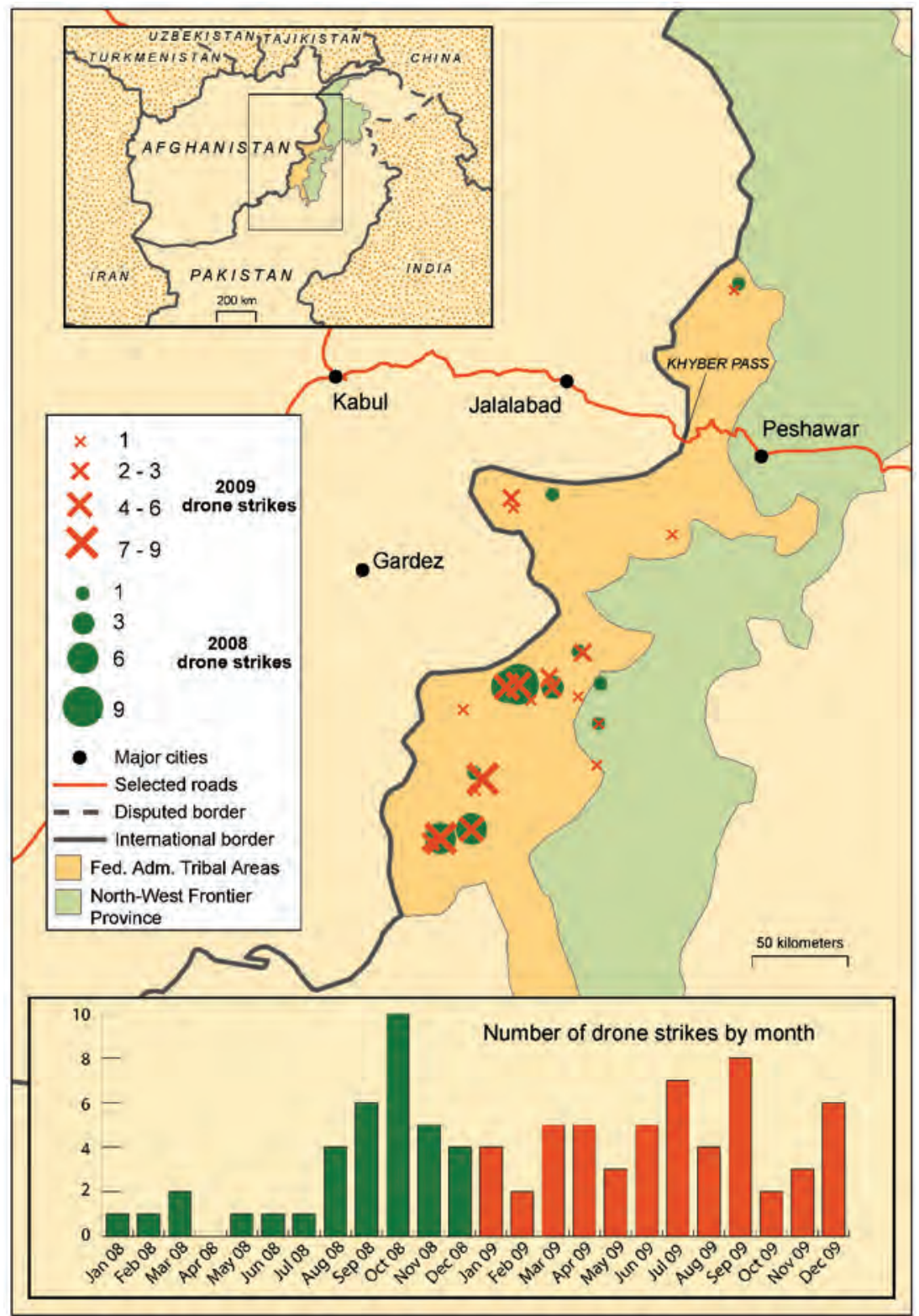

Fig. 15. Spatial and temporal distribution of drone missile attacks in Pakistan, 2008-2009.

year (2008) is most easily seen in the bar graph embedded in Figure 15, but can also be seen in the spatial distribution of the 2009 drone attacks. Some locations have experienced several drone strikes, although in some instances the drone strike occurred in an extremely remote village where certifying latitude and longitude coordinates is difficult. When this uncertainty occurs, the incidents are included in the record for the nearest location noted in media reports that has spatial reference information. 
Comparing the 2008 and 2009 missile attacks, it is clear that the 2009 strikes have occurred at many new locations. Only three strike locations in 2008 were not attacked again in 2009, while at least 10 new strike locations were added. The spatial extent (geographic range) of the drone attacks is increasing despite criticisms of the civilian costs and doubts about the legality of the practice (Glazier, 2010). As the insurgents adapt to the presence of drones (using human couriers instead of telephones for communication and changing their residences constantly), the drones' effectiveness will come more into question as the political costs to the Pakistani government rise (Fishman, 2010).

\section{CONCLUSIONS}

Our analysis of the dynamics of the wars in Afghanistan and Pakistan has taken a snapshot of the related conflicts that have been ongoing for nearly nine years, although a historian of the region could argue that they have continued for 30 years (since the Soviet invasion) or even longer. The key location of Afghanistan, bordering Central Asia and the Indian subcontinent, has long made this country an important geopolitical prize for neighboring states and external powers. The social elements that have generated strong and consistent opposition to outside control and the physical geography that has enabled local forces to harass and target invaders are certainly revisited in current discussions of the best policy options for the United States and its allies. As the war continues to become more violent, ${ }^{18}$ any discussions about a political settlement seem both premature and figments of the imaginations of commentators. We have noted the contrast between the so-called RMA tactics of the external powers, heavily funded and armed, and the guerrilla tactics of the insurgents who, in a classic manner, do not have to achieve battlefield victory but simply outlast the opposition.

The geography of the wars shows both continued concentrations of violence in the traditional mountainous locations and in southern Afghanistan, the regions of original support for the Taliban in the early 1990s. The new features of the maps and the analysis show the high volume of violence in key urban centers (Kabul, Peshawar) that both lie close to the scene of greatest fighting but are also important administrative and iconic places. The biggest development of the war over the past two years has been the incorporation of the Tribal Areas of Pakistan fully into the conflict, which has been ongoing across the Durand Line for three decades (since the Soviet invasion). While the Pakistani government was responsible for much of the support for the Pashtun-based anti-Soviet insurgency in Afghanistan, the current Zardari government is targeting alleged supporters of the Taliban within its own borders. In doing so and in supporting the U.S. policy (and seen to be secretly accepting the drone missile attacks in Pakistan), it has sparked widespread domestic opposition that threatens the foundations of the state.

We have not reported in detail on casualty figures of the conflicts because they are so unreliable. The media reports omit casualty details, provide very general estimates, or report the claims of one side (usually the government) only. However, it is evident that the casualty rate is rising quickly, an expectation about which President Obama warned Americans when he announced the 30,000 troop surge in late 2009. By their nature, media reports on which the ACLED coding relies, are selective, incomplete, sometimes biased, and subject to journalist and editorial decisions about the interest of readers. By counting, mapping, and analyzing violent events, we are only providing partial insight into the conflict, but we can show its non-random and concentrated geographic pattern. Civil wars are quite selective, both geographically and geopolitically.

\footnotetext{
${ }^{18}$ July 2010 was the most deadly for U.S. military personnel (Oppel and Mashal, 2010).
} 


\section{REFERENCES}

ACLED (Armed Conflict Location and Event Data), website [http://www.acleddata.com], last accessed July 31, 2010.

Acharya, Arabinda, Syed Bukhari, and Sadia Sulaiman, "Making Money in the Mayhem: Funding Taliban Insurrection in the Tribal Areas of Pakistan," Studies in Conflict and Terrorism, 32, 2:95-108, 2009.

Angstrom, Jan, "Inviting the Leviathan: External Forces, War, and State-Building in Afghanistan," Small Wars and Insurgencies, 19, 3:374-396, 2008.

Baddeley, Adrian, Jesper Moller, and Rasmus Plenge Waagepetersen, "Non- and Semiparametric Estimation of Interaction in Inhomogeneous Point Patterns,” Statistica Neerlandica, 54, 3:329350, 2000.

Bailey, Trevor C. and Anthony C. Gattrell, Interactive Spatial Data Analysis. Harlow, UK: Longman, 1995.

Bajoria, Jayshree, “Backgrounder: India-Afghanistan Relations,” Council on Foreign Relations, July 22, 2009 [http://www.cfr.org/publicaton/17474/indiaafghanistan_relations.html], last accessed July 31, 2010.

BBC (British Broadcasting Corporation), "Lack of Security Leading to Attacks on NATO Container Ports_Pakistan Paper,” December 13, 2008 [http://www.news.bbc.co.uk/2/hi/south_asia/7769758. stm].

Beck, Richard A., "Remote Sensing and GIS as Counter-Terrorism Tools in the Afghanistan War: A Case Study of the Zhawar Kili region,” Professional Geographer, 55, 2:170-179, 2003.

Benini, Aldo A. and Lawrence H. Moulton, "Civilian Victims in an Assymetrical Conflict: Operation Enduring Freedom in Afghanistan,” Journal of Peace Research, 41, 4:403-422, 2004.

Berman, Sheri, "From the Sun King to Karzai," Foreign Affairs, 89, 2:2-10, 2010.

Bird, Sheila and Clive Fairweather, "IEDs and Military Fatalities in Iraq and Afghanistan," The RUSI Journal, 154, 4:30-38, 2009.

Blackwill, Robert D., “A De Facto Solution for Afghanistan.” Politico, July 7, 2010 [http://www .politico.com/news/stories/0710/39432.html], last accessed July 20, 2010.

Braithwaite, Alex, "Resisting Infection: How State Capacity Conditions Conflict Contagion," Journal of Peace Research, 47, 3:311-319, 2010.

Bruk, S. I. and V. S. Apenchenko, eds., Atlas narodov mira (Atlas of the World's Peoples). Moscow, USSR: Glavnoye upravleniye geodezii i kartografii gosudarstvennogo geologicheskogo komiteta SSSR i Institut etnografii im. H. H. Miklukho-Maklaya, Akademiya nauk SSSR, 1964.

Buhaug, Halvard, Scott Gates, and Päivi Lujala, "Geography, Rebel Capability, and the Duration of Civil Conflict," Journal of Conflict Resolution, 53, 4:544-569, 2009.

Buhaug, Halvard and Kristian S. Gleditsch, "Contagion or Confusion? Why Conflicts Cluster in Space,” International Studies Quarterly, 52, 2:215-233, 2008.

Burns, John, F., "In Bold Move, Karzai Offers Safe Passage to Taliban Leader if He Agrees to Talks," New York Times, November 17, 2008.

Cederman, Lars-Erik, and Kristian Gleditsch, "Introduction to Special Issue on 'Disaggregating Civil War',” Journal of Conflict Resolution, 53, 4:487-495, 2009.

Chojnacki, Sven, "Anything New or More of the Same? Wars and Military Interventions in the International System," Global Society, 20, 1:25-46, 2006.

CIESIN/IFPRI/CIAT (Center for International Earth Science Information Network, International Food Policy Research Institute, and Centro Internacional de Agricultura Tropical),

CIVIC (Campaign for Innocent Victims in Conflict), website [www.civicworldwide.org], last accessed July 31, 2010.

“Civilian Casualty Data," Afghanistan Conflict Monitor (website), July 2010 [http://www.afghanistan conflictmonitor.org/civilian.html], last accessed August 6, 2010.

Cooper, Helene, “Avoiding Tensions, Obama Reassures Karzai,” New York Times, May 12, 2010. 
Dalby, Simon, "Geopolitics, the Revolution in Military Affairs, and the Bush Doctrine," International Politics, 46, 2-3: 234-252, 2009.

Dalrymble, William, "Why the Taliban Is Winning in Afghanistan," New Statesman, June 22, 2010 [http://www.newstatesman.com/international-politics/2010/06/british-afghanistan-government], last accessed July 2, 2010.

Danko, David M., "The Digital Chart of the World Project," Photogrammetric Engineering and Remote Sensing, 58, 8:1125-1128, 1992.

Dixon, Jeffrey, "What Causes Civil Wars?: Integrating Quantitative Research Findings," International Studies Review, 11,4:707-735, 2009.

Doll, Christopher N. H., Jan-Peter Muller, and Christopher D. Elvidge, "Night-Time Imagery as a Tool for Global Mapping of Socioeconomic Parameters and Greenhouse Gas Emissions," Ambio, 29, 3:157-162, 2000.

Elvidge, Christopher D., Kimberly E. Baugh, Eric A. Kihn, Herbert W. Kroehl, Ethan R. Davis, and Chris W. Davis, "Relation Between Satellite Observed Visible-Near Infrared Emissions, Population, Economic Activity, and Electric Power Consumption,” International Journal of Remote Sensing, 18, 6:1373-1379, 1997.

Elvidge, Christopher D., Marc L. Imhoff, Kimberly E. Baugh, Vinita Ruth Hobson, Ingrid Nelson, Jeff Safran, John B. Dietz, and Benjamin T. Tuttle, "Night-Time Lights of the World: 19941995,” ISPRS Journal of Photogrammetry and Remote Sensing, 56, 2:81-99, 2001.

Elvidge, Christopher D., Paul C. Sutton, Tilottama Ghosh, Benjamin T. Tuttle, Kimberly E. Baugh, Budhendra Bhaduri, and Edward Bright, "A Global Poverty Map Derived from Satellite Data,” Computers and Geosciences, 35, 8:1652-1660, 2009.

ESRI Data \& Maps, DVD. Redlands, CA: Environmental Systems Research Institute, 2008.

Esser, Daniel, "The City as Arena, Hub and Prey: Patterns of Violence in Kabul and Karachi," Environment and Urbanization, 16, 2:31-38, 2004.

Fair, C. Christine and Seth G. Jones, “Pakistan’s War Within,” Survival, 51, 6:161-188, 2009.

Fair, C. Christine, Clay Ramsay, and Steven Kull, Pakistani Public Opinion on Democracy, Islamist Militancy, and Relations with the U.S. Washington, DC: United States Institute for Peace and Program on International Policy Attitudes, January 7, 2008.

Fayutkin, Dan, "Stabilization and Reconstruction of Nations after Military Conflict: Afghanistan and Chechnya Case Studies,” Comparative Strategy, 28, 4:367-372, 2009.

Filkins, Dexter, “U.S. Tightens Airstrike Policy in Afghanistan,” New York Times, June 21, 2009.

Fishman, Brian, The Battle for Pakistan: Militancy and Conflict across the FATA and NWFP. Washington, DC: New America Foundation, Counterterrorism Strategy Initiative, April 2010.

Fluri, Jennifer, "Geopolitics of Gender and Violence From Below," Political Geography, 28, 4:259265, 2009.

Fotheringham, A. Stewart, "Trends in Quantitative Methods I: Stressing the Local." Progress in Human Geography 21, 2:88-96, 1997.

FP and TFFP (Foreign Policy and The Fund for Peace), “The Failed States Index 2010," 2010 [http:// www.foreignpolicy.com/articles/2010/06/21/2010_failed_states_index_interactive_map_and_ rankings], last accessed July 31, 2010.

Geller, Armando and Shah Jamal Alam, "A Socio-Political and -Cultural Model of the War in Afghanistan,” International Studies Quarterly, 12, 1:8-30, 2010.

Getis, Arthur and Janet Franklin, "Second-Order Neighborhood Analysis of Mapped Point Patterns," Ecology, 68, 3:473-477, 1987.

Glazier, David, Hearing on the Rise of the Drones II: Examining the Legality of Unmanned Targeting. Washington, DC: U.S. Committee on Oversight and Government Reform, April 28, 2010.

"Global Rural-Urban Mapping Project (GRUMP): Urban Extents," 2005 [http://sedac.ciesin.columbia .edu/plue/gpw], last accessed May 24, 2010.

Grare, Frederic, "The Evolution of Sectarian Conflicts and the Ever-Changing Face of Islamic Violence,” South Asia: Journal of South Asian Studies, 30, 1:127-143, 2007. 
Gregory, Derek, "Seeing Red: Baghdad and the Event-ful City,” Political Geography, 29, 5:266-279, 2010a.

Gregory, Derek, "War and Peace," Transactions of the Institute of British Geographers, 35, 2:154-186, 2010b.

Gritzner, Jeffrey A., "The American Presence in Afghanistan-Pakistan and the West Asian Expanse: Observations on Environment and Culture," Eurasian Geography and Economics, 51, 4:413-436, 2010.

Hegre, Håvard and Nicholas Sambanis, "Sensitivity Analysis of Empirical Results on Civil War Onset,” Journal of Conflict Resolution, 50, 4:508-535, 2006.

Hegre, Håvard, Gudrun Østby, and Clionadh Raleigh, "Poverty and Civil War Events: A Disaggregated Study of Liberia,” Journal of Conflict Resolution, 53, 4:598-623, 2009.

Herb, Guntram and David Kaplan, eds., Nested Identities; Nationalism, Territory and Scale. Lanham, MD: Rowman and Littlefield, 1999.

Human Rights Watch, "The Human Cost: The Consequence of Insurgent Attacks in Afghanistan," Human Rights Watch, 19, 6, April 2007.

ICG (International Crisis Group), Pakistan: Countering Militancy in FATA. Islamabad, Pakistan/ Brussels, Belgium: International Crisis Group, Asia Report Number 178, October 21, 2009.

Johnson, Thomas H. and M. Chris Mason, "No Sign until the Burst of Fire: Understanding the Pakistan-Afghanistan Frontier," International Security, 32, 4:41-77, 2008.

Jones, Owen Bennett, Pakistan: Eye of the Storm. New Haven, CT: Yale University Press, 2002.

Jones, Seth G., In the Graveyard of Empires: America's War in Afghanistan. New York, NY: W.W. Norton and Company, 2009.

Khan, Adeel, "Pakistan in 2007: More Violent, More Unstable," Asian Survey, 48, 1:144-153, 2007.

Kilcullen, David, The Accidental Guerilla. New York, NY: Oxford University Press, 2009.

King, Anthony, "Understanding the Helmand Campaign: British Military Operations in Afghanistan," International Affairs, 86, 2:311-332, 2010.

Kulldorff, Martin, Richard Heffernan, Jessica Hartman, Renato Assuncao, and Farzad Mostashari, "A Space-Time Permutation Scan Statistic for Disease Outbreak Detection," PLoS Medicine, 2, 3:216-224, 2005.

Kulldorff, Martin and Information Management Services, SaTScan: Software for the Spatial and Space-Time Scan Statistics, v8.2.1, 2009 [http://www.satscan.org/], last accessed May 23, 2010.

Lacina, Bethany and Nils P. Gledistch, "Monitoring Trends in Global Combat: A New Dataset of Battle Deaths," European Journal of Population, 21, 1:145-166, 2005.

MacAskill, Ewin, "Bush Limits Troop Withdrawal to 8,000 and Orders 'Quiet Surge' in Afghanistan," The Guardian, April 10, 2008.

"Mapping US Drone and Islamic Militant Attacks in Pakistan," BBC News South Asia, July 22, 2010 [http://www.bbc.co.uk/news/world-south-asia-10648909], last accessed July 23, 2010.

Markey, Daniel S., Securing Pakistan's Tribal Belt, Washington, DC: Council on Foreign Relations, CSR Report Number 36, August 2008.

Mazzetti, Mark, Jane Perlez, Eric Schmitt, and Andrew W. Lehren, "Pakistan Aids Insurgency in Afghanistan, Reports Assert,” New York Times, July 26, 2010, A1, A12.

McColl, Robert W., "The Insurgent State: Territorial Bases of Revolution," Annals, Association of American Geographers, 59, 4:613-631, 1969.

McIntyre, Nancy E., Kimberly Knowles-Yánez, and Diane Hope, "Urban Ecology as an Interdisciplinary Field: Differences in the Use of "Urban” Between the Social and Natural Sciences," Urban Ecosystems, 4, 1:5-24, 2000.

McKiernan, David, "McKiernan Outlines Challenges to Military Mission in Afghanistan," PBS Newshour (broadcast), March 17, 2009.

Mullen, Rani D., "Afghanistan in 2009: Trying to Pull Back From the Brink," Asian Survey, 50, 1:127138, 2010.

Mustafa, Daanish and Katherine Brown, "The Taliban, Public Space, and Terror in Pakistan," Eurasian Geography and Economics, 51, 4:496-512, 2010. 
New America Foundation, "The Year of the Drone: An Analysis of U.S. Drone Strikes in Pakistan, 2004-2010" (database), July 28, 2010 [http://counterterrorism.newamerica.net/drones], last accessed July 31, 2010.

NOAA/USAF (NOAA National Geophysical Data Center and U.S. Air Force Weather Agency), "DMSP-OLS Nighttime Lights Time Series, Version 4," 2009 [http://www.ngdc.noaa.gov/dmsp/ downloadV4composites.html], last accessed May 24, 2010.

Oak Ridge National Laboratory, "Landscan Global Population Dataset," 2008 [http://www.ornl.gov/ sci/landscan], last accessed February 3, 2010.

OEF (Operation Enduring Freedom), website [http://www.icasualties.org/oef], last accessed July 31, 2010.

O'Loughlin, John, "The Political Geography of Conflict: Civil Wars in the Hegemonic Shadow," in Colin Flint, ed., The Geography of War and Peace. New York, NY: Oxford University Press, 2005a, 85-112.

O'Loughlin, John, “The War on Terrorism, Academic Publication Norms, and Replication," Professional Geographer, 57, 4:588-591, 2005 b.

O'Loughlin, John and Luc Anselin, "Bringing Geography Back to the Study of International Relations: Spatial Dependence and Regional Context in Africa, 1966-1978," International Interactions 17, 1:29-61, 1991.

O'Loughlin, John, and Frank D. W. Witmer, "The Localized Geographies of Violence in the North Caucasus of Russia, 1999-2007," Annals of the Association of American Geographers, 100, 4, 2010 (forthcoming).

O'Loghlin, John, Frank D. Witmer, Andrew M. Linke, and Nancy Thorwardson, "Peering into the Fog of War: The Geography of the Wikileaks Afghanistan War Logs, 2004-2009," Eurasian Geography and Economics, 51, 4:472-495, 2010.

Oppel, Richard, Jr. and Mujib Mashal, "66 Deaths of American Troops Set a Monthly Record for the Afghan War,” The New York Times, July 31, 2010, A6.

PIPS (Pakistan Institute for Peace Studies), Pakistan Security Report 2009. Islamabad, Pakistan: Pakistan Institute for Peace Studies, 2010.

Polk, William R., “Legitimation Crisis in Afghanistan,” The Nation, April 19, 2010.

Raleigh, Clionadh and Håvard Hegre, "Population Size, Concentration, and Civil War: A Geographically Disaggregated Analysis,” Political Geography, 28, 4:224-238, 2009.

Raleigh, Clionadh, Andrew Linke, Håvard Hegre, and Joachim Carlson, "Introducing ACLED: An Armed Conflict Event Location Dataset," Journal of Peace Research, 47, 7, 2010a (forthcoming).

Raleigh, Clionadh, Frank Witmer, and John O'Loughlin, "The Spatial Analysis of War," in Robert A. Denemark, ed., The International Studies Encyclopedia, Vol. X. Oxford, UK: Wiley-Blackwell, 2010b, 6534-6553.

Ramsay, Clay, Steven Kull, Stephen Weber, and Evan Lewis, "Pakistani Public Opinion on the Swat Conflict, Afghanistan, and the US," World Public Opinion, Program on International Policy Attitudes, July 1, 2009 [http://www.worldpublicopinion.org/pipa/pdf/jul09_rpt.pdf], last accessed July 31, 2010.

Rashid, Ahmed, Taliban: The Power of Militant Islam in Afghanistan and Beyond, 2nd ed. London, UK: I.B. Tauris, 2010.

Riedel, Bruce, Peter Bergen, Frank Anderson, and Marc Sageman, Eighteen Months and Beyond: Implications of U.S. Policy in Afghanistan. Washington, DC: Middle East Policy Council, Capital Hill Conference Series on U.S. Middle East Policy, No. 59, January 7, 2010.

Ripley, Brian D., Statistical Inference for Spatial Processes. Cambridge, UK: Cambridge University Press, 1988.

Roi, M. L. and G. Smolynec, "End States, Resource Allocation and NATO Strategy in Afghanistan," Diplomacy and Statecraft, 19, 2:289-320, 2008.

Roy, Olivier, Islam and Resistance in Afghanistan. New York, NY: Cambridge University Press, 1990.

Rubin, Barnett R., The Fragmentation of Afghanistan. New Haven, CT: Yale University Press, 1995.

Rubin, Barnett R., “Saving Afghanistan,” Foreign Affairs, 86, 1:57, 2007. 
Rubin, Barnett R. and Ahmed Rashid, "From Great Game to Grand Bargain: Ending Chaos in Afghanistan and Pakistan," Foreign Affairs, 87, 6:30-44. 2008.

Shroeder, Jack, "Remote Sensing and Counter-Terrorism Tools in the Afghanistan War: Reality, Plus the Results of Media Hyperbole," Professional Geographer, 57, 4:592-597, 2005.

Shah, Niaz A., "War Crimes in the Armed Conflict in Pakistan," Studies in Conflict and Terrorism, 33, 4:283-306, 2010.

Shane, Scott, "CIA to Expand the Use of Drones in Pakistan," New York Times, December 3, 2009.

Shaw, Martin, "Risk-Transfer Militarism, Small Massacres, and the Historical Legitimacy of War," International Relations, 16, 3:343-359, 2002.

Siebeneck, Laura K., Richard M. Medina, Ikuho Yamada, and George F. Hepner, "Spatial and Temporal Analyses of Terrorist Incidents in Iraq, 2004-2006," Studies in Conflict and Terrorism, 32, 7:591-610, 2009.

Suhrke, Astri, "A Contradictory Mission? NATO from Stabilization to Combat in Afghanistan," International Peacekeeping, 15, 2:214-236, 2008.

“Taliban Shura Hiding in Balochistan, Says Admiral Mullen,” Daily Times, April 7, 2009.

Tellis, Ashley J., "Pakistan's Record on Terrorism: Conflicted Goals, Compromised Performance," Washington Quarterly, 31, 2:7-32, 2008.

"The Punjabi Taliban: Into the Heartland," The Economist, June 5, 2010, 50.

Their, J. Alexander, “Afghanistan's Rocky Path to Peace,” Current History, 109, April: 131-137, 2010.

UNAMA (United Nations Assistance Mission in Afghanistan), "UNAMA Calls for Safety First, as Civilian Casualties Rise by 14\% in 2009,” January 13, 2010.

United Nations, Resolution 1386, United Nations Security Council, December 20, 2001.

USGS (U.S. Geological Survey), "Shuttle Radar Topography Mission, 30 Arc Second Scene," College Park, MD: Global Land Cover Facility, University of Maryland, 2004.

Walsh, Declan, "Pakistan Bows to Demand for Islamic Sharia Law in Taliban Controlled Swat Valley," The Guardian, April 14, 2009.

Weidmann, Nils B., Jan Ketil Rød, and Lars-Erik Cederman, "Representing Ethnic Groups in Space: A New Dataset,” Journal of Peace Research, 2010 (forthcoming).

Wilner, Alex S., "Targeted Killings in Afghanistan: Measuring Coercion and Deterrence in Counterterrorism and Counterinsurgency," Studies in Conflict and Terrorism, 33, 4:307-329, 2010.

World Bank, "GNI Per Capita, Atlas Method (Current US\$)," 2009 [http://data.worldbank.org/ indicator/NY.GNP.PCAP.CD], last accessed August 5, 2010.

Yamada, Ikuho, and Peter A. Rogerson, “An Empirical Comparison of Edge Effect Correction Methods Applied to K-function Analysis,” Geographical Analysis, 35, 2:97-109, 2002. 